\title{
ONE-STOP SOURCE: A GLOBAL DATABASE OF INFLATION
}

\author{
Jongrim Ha \\ M. Ayhan Kose \\ Franziska Ohnsorge
}

Working Paper No: 2107

July 2021

This Working Paper is issued under the supervision of the ERF Directorate. Any opinions expressed here are those of the author(s) and not those of the Koç University-TÜSİAD Economic Research Forum. It is circulated for discussion and comment purposes and has not been subject to review by referees.

\section{KOÇ UNIVERSITY-TÜSİAD ECONOMIC RESEARCH FORUM \\ Rumelifeneri Yolu 34450 Sariyer/Istanbul}




\title{
One-Stop Source: A Global Database of Inflation
}

\author{
Jongrim Ha, M. Ayhan Kose, and Franziska Ohnsorge*
}

July 2021

\begin{abstract}
This paper introduces a global database that contains inflation series: (i) for a wide range of inflation measures (headline, food, energy, and core consumer price inflation; producer price inflation; and gross domestic product deflator changes); (ii) at multiple frequencies (monthly, quarterly and annual) for an extended time period (1970-2021); and (iii) for a large number of (up to 196) countries. As it doubles the number of observations over the next-largest publicly available sources, our database constitutes a comprehensive, single source for inflation series. We illustrate the potential use of the database with three applications. First, we study the evolution of inflation since 1970 and document the broadbased disinflation around the world over the past half-century, with global consumer price inflation down from a peak of roughly 17 percent in 1974 to 2.5 percent in 2020. Second, we examine the behavior of inflation during global recessions. Global inflation fell sharply (on average by 0.9 percentage points) in the year to the trough of global recessions and continued to decline even as recoveries got underway. In 2020, inflation declined less, and more briefly, than in any of the previous four global recessions over the past 50 years. Third, we analyze the role of common factors in explaining movements in different measures of inflation. While, across all inflation measures, inflation synchronization has risen since the early 2000s, it has been much higher for inflation measures that involve a larger share of tradable goods.
\end{abstract}

JEL Classification: E30, E31, F42

Keywords: Prices, global inflation, deflation, inflation synchronization, global factor.

* J. Ha: World Bank, Email: jongrimha@worldbank.org. M. A. Kose: World Bank; Brookings Institution; CEPR; CAMA; Email: akose@worldbank.org. F. Ohnsorge: World Bank; CEPR; CAMA, Email: fohnsorge@worldbank.org. We would like to thank Carlos Arteta, Matteo Ciccarelli, Alistair Dieppe, Anna Ivanova, Andreas Jobst, Atsushi Kawamoto, Gene KindbergHanlon, Christopher Towe, Filiz Unsal, and seminar participants at the World Bank and many other institutions for useful comments and suggestions during our work on this project. Hrisyana Doytchinova, Arika Kayastha, Jingran Wang, Xinyue Wang, and Heqing Zhao provided excellent research assistance. We gratefully acknowledge support from the PHRD Fund and the Knowledge for Change Program (KCP) III Fund. The findings, interpretations, and conclusions expressed in this paper are entirely those of the authors. They do not necessarily represent the views of the World Bank and its affiliated organizations. 


\section{Introduction}

Low and stable inflation has generally been associated with faster growth and more stable output and employment whereas both very low and very high inflation have been associated with macroeconomic challenges. ${ }^{1}$ Economies with high inflation typically experienced significantly weaker growth and extended periods of chronically high inflation frequently ended in financial crises. Conversely, persistently below-target inflation accompanied by weak growth in advanced economies since the 2007-09 global financial crisis has forced central banks to employ unconventional monetary policy instruments to support demand. This period of below-target inflation has created its own challenges: in particular, it increased risks of de-anchoring inflation expectations and risks associated with financial sector stability because of elevated asset prices.

A thorough understanding of the long-term evolution of global inflation requires a comprehensive database that covers a truly global set of countries for an extended period. Several well-known databases with selected indicators of inflation are available; however, no database systematically brings together many inflation measures for a large number of countries over a long time span. ${ }^{2}$ This paper introduces a new database of inflation that fills this gap by compiling inflation data from multiple sources, including various international institutions as well as a large number of country-specific sources.

Our database has the following advantages over others in the literature. First, it is a comprehensive database for a virtually global sample of countries over half a century: up to 37 advanced economies and 159 EMDEs for 1970-2021 (Table 1). The data coverage expands on other data sources in all inflation measures, especially for high-frequency (monthly and quarterly) inflation data. Although the country coverage of some other cross-country data sources is comparable to our database, those databases focus on only a few inflation measures, lower data frequencies, or shorter time periods. These crosscountry sources are complemented by more than 100 country-specific sources to obtain headline consumer price index (CPI)inflation, its subcomponents, and producer price indices (PPI, Table 2). The database is updated regularly and publicly available. ${ }^{3}$

Second, our database provides a balanced sample of a wide range of inflation measures (headline, core, energy and food CPI; PPI; and GDP deflator) for 25 countries from 1970 and 67 countries from 2000. To our knowledge, no other database provides such a large, balanced dataset for multiple measures of inflation over such a long sample period. This type of comprehensive and balanced sample is a prerequisite for any detailed cross-country analysis of inflation.

\footnotetext{
${ }^{1}$ For linkages between inflation and activity, see Kremer, Bick, and Nautz (2013); Easterly (2019); and Ha, Kose, and Ohnsorge (2019).

2 These cross-country data sources include the main macro database of the Organization for Economic Cooperation and Development (hereafter OECD.Stat), the International Monetary Fund's International Financial Statistics (IFS), Consumer Price Index, and World Economic Outlook (WEO) databases, databases from the International Labor Organization (ILOSTAT), and the United Nations (UNdata).

3 The database is available at: www.worldbank.org/inflation-data. It is updated twice a year.
} 
Third, the database improves the coverage (length) of time series compared with other sources. Existing cross-country data sources differ in the length of available countryspecific inflation data depending on inflation measures and data frequencies. In our database, we maximize the time coverage for each country and inflation measure by collecting data from cross-country and/or country-specific sources with the longest time series and complementing missing observations with data from other sources. For core inflation, where publicly available data is patchy, we estimate missing observations by deriving core inflation as the difference between headline inflation and the contributions of energy and food inflation. This expands the core inflation dataset by another 70 countries to 171 countries between 1970 and 2020.

As a result of our data compilation across many sources, our database constitutes a onestop source for inflation data. It has a significantly larger coverage than other databases across the six inflation measures (headline, core, food, and energy CPI; PPI; and GDP deflator) for up to 196 countries for 1970-2021. Our monthly, quarterly, and annual databases approximately double the number of observations compared with the nextlargest databases. The most extensive additions in our database are in the components of CPI inflation: for annual energy inflation, we double the number of observations over the next-largest database; for core inflation, we increase the number of observations by onehalf. A further contribution of our database is the extension of the historical data. Our database offers the full time series of annual data from 1970 for 155 countries whereas other standard cross-country databases (OECD.Stat, WEO, IFS, ILOSTAT) have such data for about 105 countries.

Fourth, beyond official price statistics available in cross-country and country-specific data sources, our database includes analytical measures of inflation that are important inputs into monetary policy decisions. For instance, we decompose individual headline CPI inflation rates for 82 countries into trend and cyclical inflation components.

We illustrate the use of our database in the context of three aspects of global inflation. First, we document the broad-based disinflation observed over the past five decades. Trend disinflation over that period manifested in all measures of inflation featured in the database. Earlier studies have documented broad-based global disinflation, but with data sets that covered a narrower set of countries or a shorter period. These studies have been mostly restricted to advanced economies and have not included the past decade of unusually low inflation, the drop in the price of oil in 2014-16, or the latest global recession in 2020. Second, we study inflation developments around global recessions since 1970 . We compare the evolution of inflation during the 2020 recession induced by the COVID-19 pandemic with inflation developments around the other global recessions over the past five decades. Third, we use a dynamic factor model to analyze the extent of inflation synchronization across the largest number of inflation measures. This application expands on earlier studies that relied on fewer inflation measures for mostly advanced-economy data.

The rest of the paper is structured as follows. In Section 2, we briefly explain different measures of inflation. Section 3 introduces our database of inflation. We describe the data sources and definitions of the variables and their construction in detail. In Section 4, as the first and second applications of the database, we document the evolution of inflation 
over time and across countries and study the evolution of global inflation around global recessions. In Section 5, we systematically explore the extent of inflation synchronization among a wide range of inflation measures based on price indexes that differ in their tradables content. Section 6 concludes.

\section{Conceptual considerations}

Before introducing the new inflation database, we briefly discuss several basic conceptual issues. These include the relationship between inflation and relative price changes, the interpretation of different measures of inflation, and the implications of inflation volatility and persistence.

Inflation, deflation, and disinflation. Inflation refers to a sustained and broad-based increase in the overall price level. ${ }^{4}$ This is distinct from changes in relative prices, which measure the price of one good or service relative to the price of another (or a weighted average of all other goods and services) and signal information about relative surpluses or shortages in different product markets. Deflation refers to negative inflation - that is, a decline in price levels - whereas disinflation refers to a decline in inflation rates that are still positive (Bordo and Filardo 2005; Federal Reserve Bank of San Francisco 1999).

Headline versus core inflation. Headline inflation usually refers to changes in the prices of all goods and services in a basket of goods and services that is representative of consumer expenditures. Core inflation is intended to capture the underlying, common trend in prices. In practice, core inflation is often measured by excluding from the calculation prices of goods and services that are most volatile, in particular food and energy. Alternatively, core inflation is sometimes calculated as the common component of price movements of all goods and services (Stock and Watson 2007, 2010; Schembri 2017).

Consumer prices, producer prices, and GDP deflators. The most common measure of inflation is the percent change in the headline consumer price index, which captures the cost of living of the average consumer. The CPI includes domestically produced and imported consumer goods. The producer price index, in contrast, reflects the overall level of prices charged by domestic producers of goods and services. ${ }^{5}$ Domestically produced goods and services can have several purposes, including domestic consumption, domestic investment, and exports. When the composition of consumption differs from that of production, for example, because of large consumer goods imports or extensive production of investment goods, CPI and PPI inflation can diverge materially. Finally, the GDP deflator measures the average price of the economy's output, broadly defined. It differs

\footnotetext{
4 When the word "inflation" was first used in economic contexts in the early- to mid-19th century, it referred to growth of the money supply. In the 1930s, it began to be associated with rising prices, which were attributed to growing money supply (Bryan 1997).

5 The wholesale price index (WPI) is closely related to the PPI but, in principle, refers to sales in the wholesale market, whereas the PPI refers to all sales. In the United States, for example, the WPI was renamed the PPI in 1978 (Bureau of Labor Statistics). In contrast, the personal consumption expenditure (PCE) index is closely related to the CPI but, in contrast to the CPI, includes services not directly paid for by consumers, for example, employer-paid services such as medical insurance.
} 
from the CPI by excluding import prices but including prices of exports, investment, and government consumption. ${ }^{6}$ It differs from the PPI by including taxes net of subsidies. The emphasis in this paper is on the CPI, because it offers the largest possible cross-country sample, especially at monthly and quarterly data frequencies, and it is the measure targeted by the largest number of central banks.

\section{Database: Measures and Country Coverage}

Measures. The database includes six measures of inflation: headline, food, energy, and core CPI inflation; PPI inflation; and GDP deflator changes at monthly, quarterly and annual frequencies (Tables 1-3). Data sources include ILOSTAT, IMF's International Financial Statistics, Consumer Price Index, and World Economic Outlook databases, OECD.Stat, UNdata, as well as a large number of country-specific sources, including central banks and statistical offices. ${ }^{7}$ Especially for the components of the CPI, these country-specific sources are critical: they expand the number of observations by 48 countries for energy inflation, 32 countries for food inflation, and 16 countries for core inflation.

As a result of our data compilation across many sources, our database has a significantly larger coverage across the six inflation measures for up to 196 countries for 1970-2021 than other cross-country sources. Our monthly, quarterly, and annual databases approximately double the number of observations compared with the next-largest databases (IMF IFS or WEO, depending on the frequency). For example, our database has roughly 37,000 annual observations compared with the IMF's IFS and WEO of about 17,000 and 14,500 observations, respectively. ${ }^{8}$ The most important additions are in the components of CPI inflation: for annual energy inflation, we double the number of observations (to 6,100) over the next-largest database (the IMF's Consumer Price Index with 2,600 observations) and for core inflation, we increase the number of observations by one-half (to 2,500 observations, compared with 1,600 observations in the OECD.Stat). A further contribution of our database is its coverage of much longer inflation series. Our database offers annual data from 1970 for 155 countries, whereas standard cross-country databases (OECD.Stat, WEO, IFS, ILOSTAT) offer such data only for 105 countries.

Country coverage. Headline inflation data are available for 193 countries, including 37 advanced countries and 156 EMDEs, including 27 LICs (based on the World Bank country

\footnotetext{
${ }^{6}$ Import and export price indexes measure changes in the price of internationally traded goods and services.

7 The WEO database includes headline CPI inflation only for 191 countries at annual frequency for the period of 1980-2020. The IFS database includes headline CPI, GDP deflator, and producer price inflation at monthly, quarterly, and annul frequencies, but does not include other inflation measures. The Consumer Price Index database includes headline CPI and its subcomponents at monthly, quarterly, and annul frequencies The OECD.Stat database provides headline, core, energy, and food consumer price inflation, and producer price inflation, but for at most 45 countries for 2000-20 (before 2000, for 30 countries). The ILOSTAT database provides headline and food price inflation for 56 countries during 2001-2020 but not for other inflation measures.

8 Our database has roughly 89,000 quarterly observations compared with the IMF's IFS of about 46,500 observations. Our monthly database has roughly 211,000 observations, compared with the about 110,000 in the IMF's IFS.
} 
classification, World Bank 2020). A complete (balanced) dataset of annual data for all six inflation measures is available for 25 countries between 1970-2020, including 20 advanced economies and 5 EMDEs. Quarterly data for headline CPI inflation is available for up to 37 advanced economies and 156 EMDEs, for 1970:1 until 2021:1. A balanced sample with quarterly data for CPI inflation available for the same period includes 27 advanced economies and 65 EMDEs. Table 4 provides a detailed breakdown of the number of countries with available data and periods.

Headline inflation. Data are drawn from multiple databases: OECD.Stat, the IMF World Economic Outlook database and International Financial Statistics, ILOSTAT, UNdata and country-specific sources including central banks and statistical offices. The IMF Consumer Price Index database for its member countries is available for long time periods, but with gaps. Country-specific sources in 11 countries provide additional data for headline CPI inflation. The combination of data from multiple sources enable us to expand the total number of observations by up to 20 percent. This expansion mostly pertains to the historical data that is typically needed for time series analysis. For example, while the next-most comprehensive cross-country database for annual inflation (the World Economic Outlook) offers the same country coverage (187 countries) as our database for 2020 , it does not offer inflation data before 1980. In contrast, our database offers such historical data for 155 countries out of the 187 countries with recent inflation data.

Food inflation. Data are drawn from four cross-country datasets as well as country-specific sources. The ILOSTAT database on CPI components has a comprehensive coverage of food prices. OECD.Stat covers OECD members and a few non-members starting in 1970. IMF Consumer Price Index database are used to fill data gaps, in particular from the 2010s. In around one-half of the countries, the time series for food price inflation is longer than the data provided by other sources. Country-specific sources provide the data for at least 74 countries. Our database more than doubles the observations over the next-largest database (ILOSTAT) for annual data, and raises them by around 40 percent for quarterly data.

Energy, core, and producer price (PPI) inflation. Data are drawn from OECD.Stat (energy, core, and PPI inflation), UNdata (energy), and the IMF's International Financial Statistics (PPI inflation) and Consumer Price Index (energy). Country-specific sources provide additional data for up to 69 countries. Data from the multiple sources are combined only if there are no large discrepancies in values between the databases. Official core inflation data are available for up to 101 countries (50 countries since 2000). For other countries, and for longer periods within countries, core inflation series are estimated using CPI weights and inflation in CPI components. The combination of the data from multiple sources more than doubles the annual observations for energy CPI inflation and it increases the number of annual, quarterly, and monthly observations for core inflation by one-half or more.

For the countries for which official measures of core inflation are not available, core inflation series are obtained by subtracting the contribution of volatile components of CPI (food and energy) from headline inflation.

For most EMDEs, and especially low income countries (LICs), monthly energy inflation 
series are not available. For these countries, the calculation of core inflation uses the housing, water, electricity, gas and other fuels category of CPI as a proxy for energy inflation. The following formula is used to calculate core inflation at every time $t$ :

$$
\text { Core inflation }=\frac{\left[\pi-\omega_{F} \pi_{F}-\omega_{E} \pi_{E}\right]}{1-\omega_{F}-\omega_{E}}
$$

where $\pi, \pi_{F}$, and $\pi_{E}$ are the current monthly inflation rates for headline, food, and energy, respectively, and $\omega_{F}$ and $\omega_{E}$ are the current weights for food and energy, respectively. The weights of the sub-indexes in the total index are obtained from various cross-country databases, including IMF Consumer Price Index, ILOSTAT, and country-specific sources. ${ }^{9}$ These calculations expand the sample for core inflation by 70 countries to 171 countries for at least one year between 1970 and 2020 .

Cyclical and trend inflation. Cyclical and trend inflation series are estimated using the univariate unobserved components-stochastic volatility model of trend inflation in Stock and Watson (2016). In their model, the rate of inflation is expressed as the sum of a permanent and a transitory (or cyclical) component; trend inflation is defined as the part of inflation that follows a permanent stochastic trend while cyclical inflation is a serially uncorrelated transitory component. These series are available on a quarterly basis for up to 82 countries from 1971.

GDP deflator. For 1970-2020, data are drawn from the World Economic Outlook database, International Financial Statistics, World Bank's World Development Index, and Federal Reserve Economic Database. This extends the dataset backwards to the 1970s for 130 countries of the 196 countries with recent data available in the World Economic Outlook. Quarterly data are available for up to 96 countries, mostly derived from International Finance Statistics and Federal Reserve Economic Data. Overall, our database expands the observations of the other data sources by up to 46 percent.

Global inflation. Global inflation is the cross-country median of inflation in a balanced set of 155 countries, of which 126 are EMDEs. The median is chosen to control for several episodes of hyperinflation, especially in the 1980s and 1990s. That said, trends in median inflation were broadly consistent with trends in unweighted or GDP-weighted average inflation (weighting by average real GDP for 2010-19). While global inflation is defined as the median for the purposes of this paper, the database also includes these unweighted and weighted average inflation rates for completeness.

Group-specific inflation. The database also includes inflation for several country groups, always based on group medians and spanning those countries with data available from 1970. The country groups include 36 advanced economies and 157 EMDEs - including 27 LICs as well as 97 EMDE commodity exporters and 60 EMDE commodity importers (as

9 The information of the following categories is obtained: food and non-alcoholic beverages; alcoholic beverages, tobacco, and narcotics; clothing and footwear; housing, water, electricity, gas and other fuels; furnishings, household equipment and routine household maintenance; health; transport; communication; recreation and culture; education; restaurants and hotels; and miscellaneous goods and services. 
defined in World Bank 2021). Aggregates are also included for the WBG's regions: 24 EMDEs in East Asia and the Pacific (EAP); 23 EMDEs in Europe and Central Asia (ECA); 36 EMDEs in Latin America and the Caribbean (LAC); 19 EMDEs in the Middle East and North Africa (MNA); 8 EMDEs in South Asia (SAR); and 47 EMDEs in SubSaharan Africa (SSA). While the remainder of this paper refers to medians for group inflation, for completeness, unweighted and GDP-weighted average inflation rates (using average real GDP for 2010-19 for weights) for all groups are also included in the database.

Global commodity price indexes. Global commodity prices and indexes are available from 1960 from the World Bank's Pink Sheet of commodity price data. The following global price indexes are available at monthly, quarterly, and annual frequencies: agricultural commodity index; energy commodity index; non-energy commodity index; and food commodity index. All indexes are in nominal U.S. dollars, scaled to $2010=100$.

\section{Evolution of global inflation}

Global annual inflation fell sharply from its 1974 peak of 16.9 percent, to 2.5 percent in 2020. This decline began in advanced economies in the mid-1980s and in EMDEs in the mid-1990s. By 2000, global inflation had stabilized at historically low levels. Lower inflation has been accompanied by lower inflation volatility, especially among advanced economies. This section discusses these developments in detail.

\subsection{Trend disinflation, $1970-2020$}

From the mid-1970s, global inflation has declined sharply. Global inflation fell from a peak of 16.9 percent in 1974 to a trough of 1.9 percent in 2015 before returning to 2.5 percent in 2020 (Figure 1). In EMDEs, inflation declined from a peak of 17.5 percent in 1974 to 3.0 percent in 2020; in LICs, it fell from a peak of 24.4 percent in 1994 to 5.9 percent in 2020. The trend decline started earlier (in the mid-1980s) in advanced economies than in EMDEs and LICs (in the mid-1990s). The downward trend has manifested in all inflation measures, including headline CPI, core CPI, PPI, and GDP deflator inflation. By the early 2000s, the disinflation was largely completed, although it resumed after the global financial crisis at a milder pace.

The "near-universal" character of disinflation since the mid-1970s was already recognized by Rogoff (2003), but most other studies have focused on advanced economies. The widely shared disinflation in advanced economies has been attributed partly to common termsof-trade shocks, such as oil price swings (Rogoff 2003). Among G7 economies (Canada, Japan, France, Germany, Italy, United Kingdom, United States), it may also have reflected changes in monetary policy regimes, including the increased focus on price stability, which also occurred during the early 1980s and early 1990s.

Other factors may have included sounder fiscal policies, deregulation, globalization, and, in the 1990s, accelerating productivity growth in parts of the world. ${ }^{10}$ Studies of

${ }^{10}$ A comprehensive discussion of these factors is presented in Ha, Kose, and Ohnsorge (2019). Several recent studies focus on the growing role of global developments in inflation dynamics and 
disinflation in EMDEs have focused on specific policy experiments in individual countries, such as the introduction of inflation targeting, greater exchange rate flexibility, or macroeconomic stabilization programs. ${ }^{11}$

1970s. In the wake of two major oil crises - the quadrupling of oil prices in 1973 and the doubling of oil prices in 1979-80 - global median inflation tripled from 4.4 percent in 1970 to 13.6 percent in 1980. Some advanced-economy central banks, freed in 1971 from the constraints of the Bretton Woods system of fixed exchange rates, aimed to support economic activity with monetary expansion. Against the backdrop of pent-up depreciation pressures, the elimination of the nominal anchor of fixed exchange rates set off an inflationary wage-price spiral with weak economic growth (often termed "stagflation").

1980s. In advanced economies, monetary policy tightening in the late 1970s and early 1980s helped rein in inflation, which declined to a median of 3 percent by 1986 from its peak of 15 percent in 1974, and helped establish central bank credibility, although often at the cost of deep recessions. In the United States, for example, short-term interest rates almost quadrupled between the end of 1976 and mid-1981. In the wake of these interest rate increases, U.S. output contracted by more than 2 percent between early 1981 and mid-1982. In some advanced economies in Europe, central banks responded more strongly and earlier to rising inflation. In several countries, disinflation was less pronounced than in the United States, but it was also accompanied by output losses in the early 1980s.

In EMDEs, disinflation was delayed by persistent large fiscal and current account deficits, often exacerbated by fixed exchange rate regimes, deteriorating terms of trade for commodity exporters, and political disruptions (Dornbusch 1986; Edwards 1989). For example, for several decades, Argentina, Brazil, Chile, Israel, Mexico, Peru, and Uruguay had experienced chronically high inflation of more than 20 percent for five or more consecutive years (Supplemental Appendix Figure A1). Multiple stabilization programs were attempted, typically resulting in recessions (Calvo and Végh 1994).

1990s. In the second half of the 1980s and during the 1990s, many EMDEs implemented macroeconomic stabilization programs and structural reforms to improve economic efficiency. These initiatives often included the removal or easing of foreign exchange market controls, trade liberalization, tighter fiscal policy, and stronger fiscal and monetary policy frameworks. In EMDEs across Europe, Central Asia, and South Asia, inflation soared, as previously centrally planned economies collapsed, and the accompanying price and exchange rate liberalization released pent-up demand pressures. Subsequent stabilization efforts were associated with deep output losses. As transition economies exited high inflation and even hyperinflation during 1989-94, output declined sharply often

in dampening the responsiveness of inflation to domestic developments (Forbes 2019; Jašová, Moessner, and Takáts 2020). Goodhart and Pradhan (2020) discuss in greater detail the role of demographics; Berganza, Borrallo, and del Rio (2018) the role of price and wage setting practices; and Gilchrist and Zakrajsek (2015) the role of access to finance; Miles et al. (2017) the role of central bank policies.

${ }^{11}$ For discussions of the roles played by monetary policy frameworks, see Cecchetti et al. (2007) and Levin and Piger (2006). For discussions of other factors, see Mishkin (2000), Bernanke et al. (2001), Mishkin and Schmidt-Hebbel (2007), and Aizenmann, Chinn, and Ito (2008). 
amid civil wars and trade embargoes (Fischer, Sahay, and Végh 1996). Within two years, on average, these economies started growing again. In Latin America and the Caribbean, renewed stabilization programs that centered around sound fiscal discipline and greater central bank independence gained traction and inflation declined (Supplemental Appendix Figure A2).

2000s. The disinflation of the 1980s and 1990s paused in the early 2000s in the run-up to the global financial crisis, partly as a result of rapidly rising energy and food prices. However, the global financial crisis ushered in a renewed period of mild disinflation toward the end of the decade and, in many advanced economies, spells of negative inflation.

2010s. After the global financial crisis, deflation or low inflation was unusually pervasive across advanced economies: in 2015, inflation was negative in more than half of the advanced economies and, in 2016, inflation was in the low single digits in three-quarters of the advanced economies. This raised concerns about low inflation, or possibly even deflation, becoming entrenched in inflation expectations (Supplemental Appendix Figure A3). To reduce the risk of falling into a deflationary environment, advanced economy central banks implemented exceptionally accommodative monetary policy after the global financial crisis, including through unconventional measures. In EMDEs, inflation fell within or below target ranges in 60 percent of inflation targeting economies (from less than 50 percent in 2007), making room for monetary policy rate cuts to support economic activity (Supplemental Appendix Figure A4).

2020. Amid widespread control measures, and associated disruptions on economic activity, to stem the spread of the COVID-19 pandemic, global inflation plunged in the first half of 2020 and recovered in the second half. We provide more details about the evolution of inflation in the next sub-section.

\subsection{Inflation during global recessions}

Some of the sharpest inflation movements over the past half-century occurred around global recessions. We briefly analyze these movements during the past five global recessions since 1970. For the purposes of this historical exploration, global inflation is defined as the cross-country median of smoothed CPI inflation rates of 25 advanced economies and 51 EMDEs. ${ }^{12}$

Identification of global recessions. Turning points of global business cycles are identified following Kose and Terrones (2015) who define global recessions as declines in per capita global gross domestic product (GDP). This results in five troughs in the global business cycle - that is, global recessions - in 1975, 1982, 1991, 2009, and 2020. Based on quarterly output data, the troughs of these global recessions were in 1975:1, 1982:4, 1991:1, 2009:1, and 2020:2. These recessions were associated with a wide range of adverse developments, including financial crises in many countries (Kose, Terrones, and Sugawara 2020).

${ }^{12}$ To smooth out one-off factors, smoothed inflation is used, defined as the 4-quarter moving average of quarter-on-quarter annualized inflation. The results are largely consistent using 9quarter centered rolling averages. The analysis is restricted to CPI inflation for lack of a sufficiently large country sample for other inflation measures for the 1975, 1982, and 1991 global recessions but it employs all measures of inflation for the 2009 and 2020 recessions. 
Global disinflation during previous global recessions. Global inflation declined sharply during past global recessions, and continued to decline even as recoveries took hold (Figure 2). Global inflation declined by a cumulative 1.5 percentage points, on average, between the year before the trough of the global recession and the year after. In the 1970s through 1990s, the inflation decline was steeper in advanced economies than EMDEs, partly due to the delayed disinflation in EMDEs with high inflation until the early 1990s. From 2000, the decline in inflation around global recessions was much more pronounced in EMDEs.

The global recession in 2009 was accompanied by a somewhat shallower and shorter-lived inflation decline, in part reflecting lower inflation at the start of the recession. In less than a year from the trough of the 2009 global recession, smoothed global inflation began to pick up. This pickup was delayed by another year after the 1991 and 1975 global recessions and by several more years following the 1982 global recession.

Global recession of 2020. The new decade opened with the deepest global recession since the end of World War II, and with the largest fraction of economies experiencing declines in per capita output since 1870 (Figure 2). As a result of the widespread economic disruptions triggered by the COVID-19 pandemic, global inflation declined by 0.7 percentage point in the four quarters ending in the trough of the global recession in 2020:2; however, it began to increase afterwards, resulting in a slight uptick for 2020 as a whole. ${ }^{13}$ In advanced economies, inflation fell by 1.2 percentage points between the year before the trough of the global recession and the year after, despite low inflation going into the recession. Meanwhile, EMDE inflation also ticked up for 2020 as a whole, notwithstanding a short-lived dip in the trough of the global recession in 2020:2. ${ }^{14}$ In just below half (45 percent) of EMDEs, inflation declined over the course of 2020.

These stylized facts are broadly consistent across different inflation measures (Table 5). Inflation fluctuations were the most volatile in producer price inflation: between one year before and the trough of the global recession in 2020, global PPI inflation declined by 3.6 percentage points, partly reflecting the large effects of oil price plunges in 2020. Global core CPI inflation and GDP deflator growth also declined at a similar pace as global headline CPI inflation in the first half of 2020 before ticking up in the second half. During the second half of 2020, PPI and headline CPI inflation rebounded, in particular in EMDEs. That said, in advanced economies, inflation declined further (GDP deflator) or

\footnotetext{
13 Based on monthly data (without smoothing), global consumer price inflation declined by 0.9 percentage point between January and May 2020 (based on monthly data in 81 countries). Since May 2020, however, inflation has picked up to return to pre-pandemic levels. For details, see Ha, Kose, and Ohnsorge (2021).

${ }^{14}$ Based on monthly inflation rates (year on year), inflation in advanced economies plunged in March and April 2020, amid severe output contractions, and then remained near-nil throughout the remainder of the year (Supplemental Appendix Figure A5). Inflation in EMDEs similarly declined during the first half of 2020 (especially in EAP, LAC, and MNA), but it rose to around 3 percent in the second half. By April 2021, inflation had returned to pre-pandemic (January 2020) rates in advanced economies and EMDEs alike.
} 
remained low or negative (PPI, headline and core CPI) in the same period.

The broad-based declines in 2020 of the inflation measures were consistent with those around the 2009 global recession; however, they were more muted and more quickly reversed in 2020 than in 2009. Around the 2009 global recession, it took about a year after the trough of the recession for headline and core CPI inflation to rebound whereas, in 2020, they began to rebound within a quarter.

\subsection{Broad-based disinflation}

The disinflation over the past few decades has been broad-based across country groups (Figure 3). This has been reflected in headline inflation, core inflation, and energy and food price inflation. In the average EMDE, domestic food and energy prices constitute 52 percent of domestic consumer price baskets, and in the average advanced economy, 38 percent. Notwithstanding some sharp temporary swings, overall over the past four to five decades, food prices have been an important contributor to the persistent and steady decline in global inflation, whereas energy prices mainly have contributed to declining inflation during major oil price plunges.

Food prices have accounted for almost one-third of the almost 15 percentage point decline in global headline inflation between 1974 and 2020 as well as for occasional bouts of rising or declining headline inflation. Yet, the food CPI has reflected global food commodity price developments only to a limited degree (Figure 3). Especially in advanced economies, the estimated pass-through from international food prices to domestic food prices has been modest.

Energy prices have contributed to global disinflation only in episodes of major oil price plunges, most recently in 2014-16 and again in 2020. ${ }^{15}$ Cumulatively, energy prices have accounted for around one-fifth of the almost 15 percentage point decline in headline global inflation between 1974 and 2020. Energy price inflation has fallen well below its 1970s peaks, and was broadly stable throughout the 1990s and 2000s.

Subsidies, offsetting exchange rate fluctuations, and a growing domestic services content of the final price to consumers often drive a wedge between domestic food and energy prices and global commodity prices. Domestic energy price inflation is even less homogeneous across EMDEs than domestic food inflation, possibly reflecting a wide variety of fuel tax or subsidy schemes.

\section{Explaining global inflation}

The previous section has established the broad-based disinflation until the early 2000s and subsequent low inflation. The broad-based nature of these trends suggests that common global factors are at work. This section estimates the role of these common factors in explaining movements in different measures of inflation.

15 Reflecting the large oil price plunges in crude oil prices (World Bank 2020), energy price (median across monthly inflation in 37 countries) dropped by around 10 percentage points between end-2019 and June 2020. Since then, oil prices have recovered well above their end-2019 levels. 


\subsection{Methodology}

A dynamic factor model is employed to decompose inflation in each country into a global inflation factor that is shared across all countries, an advanced-economy or EMDE factor that is shared within the respective groups (that is, two group-specific inflation factors, one for advanced economies and one for EMDEs), and an idiosyncratic inflation factor that is unique to each individual country. ${ }^{16}$ The degree of global inflation synchronization is measured by the share of the variance of national inflation attributable to the global factor. In a similar fashion, the extent of inflation synchronization within each country group is measured by the fraction of variance that is explained by the group-specific factor.

Thus, the inflation equation for each country takes the following form:

$$
\pi_{i, t}=\beta_{\text {Global }}^{i} f_{t}^{\text {Global }}+\beta_{\text {Group }}^{i} f_{t}^{\text {Group }}+\varepsilon_{i, t}
$$

where $\pi_{i}$ denotes inflation in country $i$; the global and country-group factors are represented by $f_{t}^{\text {Global }}$ and $f_{t}^{\text {Group }}$ respectively; and the coefficients before them $(\beta)$, typically referred to as factor loadings, capture the sensitivity of inflation to these factors. The error terms $\left(\varepsilon_{i, t}\right)$ are assumed to be uncorrelated across countries at all leads and lags. The error terms and factors follow an autoregressive process.

The importance of each factor in explaining inflation is measured by the fraction of total variance of inflation due to the respective factor. This is computed by applying the variance operator to each equation in the system. Specifically, for inflation in country $i$ :

$$
\operatorname{Var}\left(\pi_{i}\right)=\left(\beta_{\text {Global }}^{i}\right)^{2} \operatorname{Var}\left(f^{\text {Global }}\right)+\left(\beta_{\text {Group }}^{i}\right)^{2} \operatorname{Var}\left(f^{\text {Group }}\right)+\operatorname{Var}\left(\varepsilon^{\pi, i}\right)
$$

Since there are no cross-product terms between the factors, the variance of inflation attributable to the global factor is:

$$
\frac{\left(\beta_{\text {global }}^{i}\right)^{2} \operatorname{Var}\left(f^{\text {Global }}\right)}{\operatorname{Var}\left(\pi_{i}\right)}
$$

The variance shares due to the group factors and idiosyncratic terms are calculated using a similar approach.

To document the differences across different inflation measures, a dynamic factor model is estimated using five measures of inflation with varying tradables content (headline CPI,

${ }^{16}$ These types of models are used extensively to analyze global business and financial cycles (Kose, Otrok, and Prasad 2012; Ha et al. 2020; Neely and Rapach 2011; Mumtaz and Surico 2012). The model is estimated using Bayesian techniques as described in Kose, Otrok, and Whiteman (2003). 
core CPI, PPI, GDP deflator, and import prices). ${ }^{17}$ Global and group-specific factors for each inflation measure are estimated for annual data for the 38 countries (25 advanced economies and 13 EMDEs) with available data for all five measures over 1971-2020 for the full sample, and over three sub-sample periods with roughly equal length: 1971-1986, 1987-2002, and 2003-2020.

\subsection{Behavior of global inflation}

Global factors were typically more volatile for inflation measures with greater tradables content. Global factors for PPI and for import price inflation tended to move together over the past five decades, but with considerably greater variability in the global factor for import price inflation - as may be expected for goods prices that are heavily exposed to, if not determined in, global markets (Figure 4). During global recessions and episodes of large oil price swings, the global PPI and import price factors exhibited sharper movements than the global headline CPI factor. With a larger share of services and nontradable goods in the GDP deflator, the global factor for the GDP deflator was considerably less volatile than those for headline CPI, PPI and import price inflation.

Since the mid-1980s, the global factor for core $C P I$ inflation - which contains the largest share of non-tradable goods and services among the inflation measures examined herehas been less volatile than those for the other inflation measures. This may reflect the exclusion of energy prices (which tend to comove globally) as well as strengthened monetary policy frameworks and better-anchored inflation expectations as a growing number of central banks succeeded in lowering inflation from high levels and began to employ inflation targeting frameworks (Figure 4). The de-coupling of core inflation from other inflation measures was also reflected in declining correlations between the global factors for core CPI and other measures of inflation. Thus, the correlation of the global factor for core CPI inflation with that for producer price inflation halved between 197186 (0.4) and 2003-20 (0.2) while the correlation of PPI or headline CPI inflation with import price inflation remained high, at around 0.8 .

\subsection{Drivers of global inflation}

The estimated global factor's share in inflation variance was higher the greater the tradable goods and services content of the basket (Table 6). For example, the global factor's largest share of inflation variation was found for import prices (55 percent in the median country) and its smallest share for core CPI inflation (10 percent). The variance share of the global factor for PPI inflation was 48 percent and that for consumer price was 31 percent. The variance share for GDP deflator growth was comparable to that for core CPI inflation (16 percent).

\footnotetext{
17 In price indices for the United States, for example, the share of tradable goods and services is greatest for the PPI (54 percent), followed by the headline CPI (53 percent), GDP deflator (26 percent), and core CPI (15 percent) (U.S. Bureau of Labor Statistics). Our classification of sectors into tradables and non-tradables follows the earlier literature; agriculture, hunting, forestry and fishing, mining and quarrying and manufacturing are classified as tradable sectors and the rest as non-tradable (Knight and Johnson 1997).
} 
In contrast to the results for the global factor, the group-specific inflation factor accounted for a similar variance share (3-6 percent) across inflation measures. For core CPI, the median variance shares of group-specific factor (4.4 percent) was around half of the share of the global factor. For import prices and PPIs, the variance shares of group-specific factors (3-5 percent) were largely minor compared to that of global factor. Variance shares of the global and group-specific factors were much larger for advanced economies than EMDEs, especially for core and headline CPI inflation and GDP deflator.

\subsection{Evolution of inflation synchronization: different measures}

Trends in inflation synchronization over time were similar across the five inflation measures (Table 6; Figure 5). This is illustrated by estimates of the model for three approximately equal subperiods: 1971-86, 1987-2002, and 2003-20. The first period, 197186, overlaps with the Great Inflation of 1965-84; the second, 1987-2002, was a period of widespread disinflation; and the third, 2003-20, was a period of low but typically stable inflation (Bryan 2018). During 1971-86, the role of the global inflation factor was sizable for all five inflation measures except core CPI inflation; global inflation synchronization weakened during 1987-2002 but returned in the 2000s and 2010s to levels similar to those of 1971-86. The median variance share of the global inflation factor was 65 percent for inflation in import prices, followed by PPIs (54 percent) and core CPIs (5 percent).

The generally lower variance share of global factors for core CPI inflation than for other inflation measures may reflect the smaller tradables content in consumption baskets than in other inflation aggregates. The median share of global factors in core inflation variation is much larger in advanced economies (24 percent) than in EMDEs (2.4 percent), possibly reflecting greater synchronization of business cycles and monetary policies in advanced economies. The share of global factors in import price inflation variation is sizable in both advanced economies (58 percent) and EMDEs (48 percent).

During 1971-86, the variance share of the global factor was greater than, or as sizable as, that of the group-specific factor for all inflation measures except core CPI inflation. During 1987-2002, however, the variance share of the global inflation factor fell to, or below, 10 percent for all five measures while the share of the group-specific factor rose to match or even exceed that of the global factor for all inflation measures. Since 2003, the variance share of the global inflation factor has risen for all inflation measures, in particular in headline and core CPI inflation.

\section{Conclusion}

A thorough understanding of the long-term evolution of global inflation requires a comprehensive database that covers a truly worldwide sample of countries. We introduce a single, one-stop source for inflation data in this paper. Although several cross-country database are available that include selected indicators of inflation, no database systematically brings together multiple measures (including headline, food, energy, and core consumer price inflation; producer price inflation; and gross domestic product deflator changes) for such a large number of countries over such a long period. 
We put together inflation data from multiple cross-country and country-specific sources with the widest cross-country, cross-measure, and over-time coverage yet. As a result of our extensive data compilation effort across many sources, our database has twice the number of observations for our six inflation measures (headline, core, energy, and food CPI, PPI, GDP deflator) for up to 196 countries for 1970-2021 than the next largest inflation database. Our addition of national sources expands, especially, the country coverage for energy, food price, and core inflation by up to 48, 32, and 16 countries, respectively. Our database also extends the historical data that is typically needed for time series analysis.

We apply the inflation database to analyze three issues: the evolution of inflation over the past five decades, the behavior of inflation during global recessions, and the synchronization of inflation over time and across country groups.

First, we document the broad-based disinflation over the past five decades. Earlier studies have documented global disinflation, but with data sets that covered a narrower set of countries or a shorter time period. These studies have been mostly restricted to advanced economies and have not taken account of either the drop in the price of oil in 2014 or the period of unusually depressed inflation during the 2010s. Trend disinflation over the past five decades manifested in all measures of inflation, in most countries, all EMDE regions, and all components of inflation. Global inflation fell from a peak of roughly 17 percent in 1974 to 2.5 percent in 2020 . In advanced economies, it has fallen steadily since the mid1980s and in EMDEs since the mid-1990s. In EMDEs, inflation declined from a peak of 17.5 percent in 1974 to 3.1 percent in 2020; in LICs, it fell from a peak of 25.2 percent in 1994 to 4.1 percent in 2020 .

Second, during global recessions, global inflation fell steeply-and continued to fall for one to three years past the trough of the global recession. The inflation decline in advanced economies in the COVID-19-induced global recession in 2020 resembled that in earlier global recessions. As a result of the widespread economic disruptions, global inflation declined in the four quarters ending in the trough of the global recession in the second quarter of 2020, but it began to increase afterwards. While the general pattern resembled that in previous global recessions, the decline in global inflation at the beginning of the 2020 recession was more muted, and its subsequent rebound earlier and faster than after previous global recessions.

Finally, by using a dynamic factor model, we analyze global inflation synchronization across a wide range of countries and inflation measures. Our results suggest that global inflation synchronization has broadened over the past half-century - across both types of goods and types of countries. In the 1970s and early- to mid-1980s, the extent of inflation synchronization was pronounced only for inflation measures with a large portion of tradable goods and services (import prices and producer prices); it has more recently become sizeable across all inflation measures. During 1970-2020, it was most pronounced for the inflation measures with the largest share of tradables: it was largest for import prices (55 percent), followed by PPI, headline CPI, GDP deflator, and core CPI (10 percent). Since the early 2000s, it has grown to around one-quarter even for core CPI inflation and GDP deflator growth. 
Our database can be used to analyze various additional questions. For example, it is possible to examine the contributions of long-term structural changes to global disinflation over recent decades by combining our comprehensive database of inflation with other economic variables that reflect country characteristics. These could include monetary and exchange regimes, trade and financial openness, and the degree of participation in global value chains. One can also study the links between country-specific business cycles and inflation, expanding on our analysis of inflation developments during global recessions. Another avenue for future work could be to assess the degree of comovement in long-term inflation trends using a more refined measure of trend inflation, such as trends of different frequencies based on a frequency domain analysis. 


\section{References}

Aizenman, J., M. D. Chinn, and H. Ito. 2008. "Assessing the Emerging Global Financial Architecture: Measuring the Trilemma's Configurations over Time." NBER Working Paper 14533, National Bureau of Economic Research, Cambridge, MA.

Berganza, J. C., Borrallo F., del Río P. 2018. "Determinants and Implications of Low Global Inflation Rates." In: Ferrara L., Hernando I., Marconi D. (eds) International Macroeconomics in the Wake of the Global Financial Crisis. Financial and Monetary Policy Studies, vol 46. Springer, Cham. Bernanke, B. S., T. Laubach, F. S. Mishkin, and A. S. Posen. 2001. Inflation Targeting: Lessons from the International Experience. Princeton University Press.

Bordo, M., and A. Filardo, 2005. "Deflation in a historical perspective." BIS Working Papers 186, Bank for International Settlements.

Bryan, M. F. 1997. "On the Origin and Evolution of the Word Inflation." Economic Commentary, Federal Reserve Bank of Cleveland, Cleveland, $\mathrm{OH}$.

Bryan, M. F. 2018. "The Great Inflation." Federal Reserve History Series, Federal Reserve Bank of Atlanta, Atlanta, GA.

Calvo, G. A., and C. A. Végh. 1994. "Inflation Stabilization and Nominal Anchors." Contemporary Economic Policy XII (April): 35-45.

Cecchetti, S. G., P. Hooper, B. C. Kasman, K. L. Schoenholtz, and M. Watson. 2007. "Understanding the Evolving Inflation Process." U.S. Monetary Policy Forum 2007, Washington, DC.

Dincer, N., and B. Eichengreen. 2014. "Central Bank Transparency and Independence: Updates and New Measures." International Journal of Central Banking 10 (1): 189-259.

Dornbusch, R. 1986. "Flexible Exchange Rates and Excess Capital Mobility." Brookings Papers on Economic Activity 1986 (1): 209-26.

Easterly, W. 2019. "In Search of Reforms for Growth: New Stylized Facts on Policy and Growth Outcomes." NBER Working Paper 26318, National Bureau of Economic Research, Cambridge, MA.

Edwards, S. 1989. "Real Exchange Rates in the Developing Countries: Concepts and Measurement." NBER Working Paper 2950, National Bureau of Economic Research, Cambridge, MA.

Federal Reserve Bank of San Francisco. 1999. What Is Deflation and How Is It Different from Disinflation? Federal Reserve Bank San Francisco, San Francisco, CA.

Fischer, S., R. Sahay, and C. A. Vogt. 1996. "Stabilization and Growth in Transition Economies: The Early Experience." Journal of Economic Perspectives 10 (2): 45-66.

Forbes, K. 2019. "Inflation Dynamics: Dead, Dormant, or Determined Abroad?" Brookings Papers on Economic Activity Fall 2019: 257-319. .

Gilchrist, S. and E. Zakrajsek. 2015. "Customer Markets and Financial Frictions: Implications for 
Inflation Dynamics." Proceedings of the Jackson Hole Symposium. Federal Reserve Bank of Kansas City, pgs. 1-52.

Goodhart, C and M Pradhan. 2020. The Great Demographic Reversal: Ageing Societies, Waning Inequality, and an Inflation Revival, London, UK: Palgrave MacMillan.

Ha, J., A. Ivanova, P. Montiel, and P. Pedroni. 2019. "Inflation in Low-Income Countries." World Bank Policy Research Working Paper No. 8934.

Ha, J., M. A. Kose and F. Ohnsorge. 2019. Inflation in Emerging and Developing Economies: Evolution, Drivers and Policies, Washington, D.C., World Bank.

Ha, J., M. A. Kose and F. Ohnsorge. 2021. "Inflation During the Pandemic: What happened? What is next?", Working Paper, Washington, D.C., World Bank.

Ha, J., M. A. Kose, C. Otrok, and E. S. Prasad. 2020. "Global Macro-Financial Cycles and Spillovers." NBER Working Paper 26798, National Bureau of Economic Research, Cambridge.

Jašová, M., R. Moessner, and E. Takáts. 2020. "Domestic and Global Output Gaps as Inflation Drivers: What Does the Phillips Curve Tell?" Economic Modelling 87: 238-253.

Knight, G., and L. Johnson, 1997, "Tradables. Developing Output and Price Measures for Australia s Tradable and Non-tradable Sectors." ABS Working Paper 97(1).

Kose, M. A., C. Otrok, and C. Whiteman. 2003. "International Business Cycles: World, Region, and Country-Specific Factors." American Economic Review 93 (4): 1216-39.

Kose, M. A., C. Otrok, and E. Prasad. 2012. "Global Business Cycles: Convergence or Decoupling?" International Economic Review 53 (2): 511-38.

Kose, M. A., N. Sugawara, and M. E. Terrones. 2019. "What Happens During Global Recessions?" In $A$ Decade after the Global Recession: Lessons and Challenges for Emerging and Developing Economies, edited by M. A. Kose and F. Ohnsorge, 55-114. Washington, DC: World Bank.

Kose, M. A., N. Sugawara, and M. E. Terrones. 2020. "Global Recessions." CEPR Discussion Paper 14397, Center for Economic Policy Research, London, U.K.

Kose, M. A., and M. E. Terrones. 2015. Collapse and Revival: Understanding Global Recessions and Recoveries. Washington, DC: International Monetary Fund.

Kremer, S., A. Bick, and D. Nautz. 2013. "Inflation and Growth: New Evidence from a Dynamic Panel Threshold Analysis." Empirical Economics 44 (2): 861-78.

Levin, A. T., and J. M. Piger. 2006. "Is Inflation Persistence Intrinsic in Industrial Economies?" Working Paper, University of Oregon.

Miles, D., U. Panizza, R. Reis and Á. Ubide. 2017. "And Yet it Moves: Inflation and the Great Recession." Geneva Reports on the World Economy \#19, Center for Economic Policy Research, London, UK.

Mishkin, F. S. 2000. "Inflation Targeting in Emerging-Market Countries." American Economic Review 90 (2): 105-09. 
Mishkin, F., and K. Schmidt-Hebbel. 2007. "Does Inflation Targeting Make a Difference?" NBER Working Paper 12876, National Bureau of Economic Research, Cambridge, MA.

Mumtaz, H., and P. Surico. 2012. "Evolving International Inflation Dynamics: World and Country-Specific Factors." Journal of the European Economic Association 10 (4): 716-34.

Neely, C. J., and D. E. Rapach. 2011. "International Comovements in Inflation Rates and Country Characteristics." Journal of International Money and Finance 30 (7): 1471-90.

Rogoff, K. 2003. "Globalization and Global Disinflation." Federal Reserve Bank of Kansas City Economic Review 88 (4): 45-78.

Schembri, L. 2017. "Getting to the Core of Inflation." Remarks at the Department of Economics, Western University, London, Ontario, February 9.

Stock, J. H., and M. W. Watson. 2007. "Why Has U.S. Inflation Become Harder to Forecast?" Journal of Money, Credit and Banking 39 (1): 3-33.

Stock, J. H., and M. W. Watson. 2010. "Modeling Inflation after the Crisis." NBER Working Paper 16488, National Bureau of Economic Research, Cambridge, MA.

Stock, J. H., and M. W. Watson. 2016. "Core Inflation and Trend Inflation." Review of Economics and Statistics 98 (4): 770-84.

World Bank. 2020. Global Economic Prospects, June. Washington, DC: World Bank.

World Bank. 2021. Global Economic Prospects. January. Washington, DC: World Bank. 
Table 1. Coverage of inflation data across different sources

\begin{tabular}{|c|c|c|c|c|c|c|c|c|c|}
\hline & \multicolumn{4}{|c|}{ Since 1970} & \multicolumn{5}{|c|}{ Since 2000} \\
\hline & $\begin{array}{c}\text { New } \\
\text { Database }\end{array}$ & OECD & IFS & ILO & $\begin{array}{c}\text { New } \\
\text { Database }\end{array}$ & OECD & IFS & WEO & $\mathrm{ILO}$ \\
\hline \multicolumn{10}{|l|}{ Headline inflation } \\
\hline Annual & 155 & 30 & 94 & 27 & 187 & 45 & 169 & 185 & 55 \\
\hline Quarterly & 92 & 30 & 91 & fi & 163 & 45 & 163 & fi & fi \\
\hline Monthly & 83 & 28 & 81 & 25 & 157 & 43 & 156 & fi & 51 \\
\hline \multicolumn{10}{|l|}{ Food inflation } \\
\hline Annual & 130 & 23 & fi & 20 & 156 & 41 & fi & fi & 50 \\
\hline Quarterly & 24 & 23 & fi & fi & 69 & 41 & fi & fi & fi \\
\hline Monthly & 23 & 21 & fi & 18 & 63 & 39 & fi & fi & 45 \\
\hline \multicolumn{10}{|l|}{ Energy inflation } \\
\hline Annual & 83 & 17 & fi & fi & 126 & 38 & fi & fi & 32 \\
\hline Quarterly & 19 & 17 & fi & fi & 60 & 38 & fi & fi & 41 \\
\hline Monthly & 19 & 16 & fi & fi & 53 & 36 & fi & fi & 37 \\
\hline \multicolumn{10}{|l|}{ PPI inflation } \\
\hline Annual & 30 & 8 & 25 & fi & 67 & 38 & 66 & fi & fi \\
\hline Quarterly & 25 & 8 & 22 & fi & 65 & 33 & 63 & fi & fi \\
\hline Monthly & 24 & 8 & 17 & fi & 61 & 32 & 58 & fi & fi \\
\hline \multicolumn{10}{|l|}{ Core inflation } \\
\hline Annual & 25 & 18 & fi & fi & 50 & 38 & fi & fi & fi \\
\hline Quarterly & 18 & 18 & fi & fi & 49 & 38 & fi & fi & fi \\
\hline Monthly & 17 & 17 & & & 47 & 34 & fi & fi & fi \\
\hline \multicolumn{10}{|l|}{ GDP deflator } \\
\hline Annual & 130 & fi & 84 & fi & 183 & fi & 159 & 182 & fi \\
\hline Quarterly & 13 & fi & 4 & fi & 66 & fi & 52 & fi & fi \\
\hline
\end{tabular}

Notes: Coverage of inflation data of based on the observations at May 2021. Balanced annual headline CPI inflation from WEO starts from 1980. "fi" indicates data are not available. See Section 3 for details on data sources. 
Table 2. Data from country sources

A. Coverage of inflation data by central bank websites

(Number of countries)

\begin{tabular}{l|c|c|c}
\hline Inflation measure & Annual & Quarterly & Monthly \\
\hline \hline Headline CPI & 59 & 18 & 100 \\
Energy CPI & 30 & 10 & 69 \\
Food CPI & 38 & 11 & 74 \\
Core CPI & 8 & 3 & 26 \\
PPI & 24 & 18 & 46 \\
GDP deflator & 3 & 2 & $\mathrm{fi}$ \\
\hline
\end{tabular}

\section{B. Coverage of country-specific inflation data}

\begin{tabular}{l|l}
\hline \hline Inflation measure & Country code \\
\hline \hline Headline CPI (M, 5) & ARG, BLR, IRL, ISL, MOZ \\
\hline Core CPI (M, 13) & $\begin{array}{l}\text { IRQ, KOR, LKA, MDA, MUS, MYS, NPL, PER, PHL, SGP, TZA, UGA, } \\
\text { UKR }\end{array}$ \\
\hline Food CPI (M, 25) & $\begin{array}{l}\text { BRB, CAN, CUW, DOM, GHA, GIN, GMB, IDN, ISL, ISR, LBY, LKA, } \\
\text { ZWI, NIC, PRT, PSE, RUS, SLB, SLE, SVK, SYC, UGA, WSM, ZMB, } \\
\text { ZWE }\end{array}$ \\
\hline Energy CPI (M, 46) & $\begin{array}{l}\text { ARG, BEN, BGD, BLZ, BRB, BWA, CHN, CUW, DOM, ECU, FJI, GHA, } \\
\text { NPL, OMN, PHL, PRY, PSE, RUS, RWA, SAU, SGP, SLB, SLE, SLV, SYC, } \\
\text { TZA, UGA, UKR, URY, VEN, VNM, WSM, ZMB, ZWE }\end{array}$ \\
\hline PPI (M, 17) & BGD, CHN CRI, EGY, GHA, IDN, IND, KAZ, MDA, NIC, PSE, RWA, \\
\hline Headline CPI (Q, 5) & SGP, URY, VEN, WSM, ZAF \\
\hline Food CPI (Q, 4) & BLZ, CYM, NZL, SVK \\
\hline Energy CPI (Q, 4) & BLZ, CYM, NZL, SVK \\
\hline PPI (Q, 6) & ALB, FJ, IDN, IND, SLB, VEN \\
\hline GDP Deflator (Q,1) & SGP \\
\hline Headline CPI (A,6) & CHN, CUW, CYM, PER, PSE, SUR \\
\hline Food CPI (A, 12) & ALB, BLZ, CHN, CUW, IDN, LBY, LKA, MDV, MLT, NIC, SUR, UGA \\
\hline Energy CPI (A, 11) & ALB, BLZ, CHN, CUW, IDN, LKA, MLT, NIC, VEN, WSM, ZWE \\
\hline PPI (A, 7) & CHN, MAR, MDA, PSE, SRB, VEN, VNM \\
\hline Core CPI (A, 6) & MAR, PER, PHL, SGP, SRB, VNM \\
\hline
\end{tabular}

Note: This table indicates the countries (denoted by IMF country code) where the corresponding inflation measures are available only from country-specific sources, or the data from country-sources cover a longer sample period than those provided by other public sources. "M", "Q", and "A" indicate that the data frequency is monthly, quarterly, and annual, respectively. Numbers in the parenthesis are the number of countries. 
Table 3. List of variables in the database

A. Country-specific inflation data

\begin{tabular}{|c|c|c|c|c|}
\hline \multirow{2}{*}{$\begin{array}{l}\text { Variable } \\
\text { Name }\end{array}$} & \multirow[b]{2}{*}{ Description (Indicator type, frequency) } & \multicolumn{2}{|c|}{ Sample } & \multirow[b]{2}{*}{ Main sources } \\
\hline & & Period & $\begin{array}{c}\text { \# of } \\
\text { countries }\end{array}$ & \\
\hline $\mathrm{HCPI}_{-} \mathrm{M}$ & Headline consumer price index, monthly & $1970 \mathrm{~m} 1-2021 \mathrm{~m} 5$ & 183 & \multirow{3}{*}{$\begin{array}{l}\text { IMF (IFS database, WEO database); } \\
O E C D . S t a t ; I L O S T A T ; U N d a t a ; \\
\text { country-specific sources }\end{array}$} \\
\hline HCPI_Q & Headline consumer price index, quarterly & 1970Q1-2021Q1 & 187 & \\
\hline $\mathrm{HCPI}_{-}^{-} \mathrm{A}$ & Headline consumer price inflation, annual & $1970-2020$ & 193 & \\
\hline FCPI_M & Food price index, monthly & $1970 \mathrm{~m} 1-2021 \mathrm{~m} 5$ & 148 & \multirow{3}{*}{$\begin{array}{l}\text { IMF (Consumer Price Index); } \\
\text { OECD.Stat; ILOSTAT; UNdata; } \\
\text { country-specific sources }\end{array}$} \\
\hline FCPI_Q & Food price index, quarterly & 1970Q1-2021Q1 & 162 & \\
\hline $\mathrm{FCPI}_{-}^{-} \mathrm{A}$ & Food price inflation, annual & $1970-2020$ & 179 & \\
\hline ECPI_M & Energy price index, monthly & $1970 \mathrm{~m} 1-2021 \mathrm{~m} 5$ & 85 & \multirow{3}{*}{$\begin{array}{l}\text { IMF ( Consumer Price Index); } \\
\text { OECD.Stat; ILOSTAT; UNdata; } \\
\text { country-specific sources }\end{array}$} \\
\hline $\mathrm{ECPI}_{-}^{-} \mathrm{Q}$ & Energy price index, quarterly & 1970Q1-2021Q1 & 148 & \\
\hline ECPI_A & Energy price inflation, annual & $1970-2020$ & 170 & \\
\hline CCPI_M & Official core consumer price index, monthly & $1970 \mathrm{~m} 1-2021 \mathrm{~m} 5$ & 82 & \multirow{3}{*}{$\begin{array}{l}\text { OECD.Stat; ILOSTAT; UNdata; } \\
\text { country-specific sources }\end{array}$} \\
\hline $\mathrm{CCPI}_{-}^{-} \mathrm{Q}$ & Official core consumer price index, quarterly & 1970Q1-2021Q1 & 85 & \\
\hline $\mathrm{CCPI}_{-} \mathrm{A}$ & Official core consumer price inflation, annual & $1970-2020$ & 101 & \\
\hline PPI_M & Producer price index, monthly & $1970 \mathrm{~m} 1-2021 \mathrm{~m} 4$ & 97 & \multirow{3}{*}{$\begin{array}{l}\text { IMF (IFS database); OECD.Stat; } \\
\text { country-specific sources }\end{array}$} \\
\hline $\mathrm{PPI} \mathrm{Q}$ & Producer price index, quarterly & 1970Q1-2021Q1 & 102 & \\
\hline $\mathrm{PPI}_{-}^{-} \mathrm{A}$ & Producer price index, annual & $1970-2020$ & 113 & \\
\hline $\mathrm{DEF}_{-} \mathrm{Q}$ & GDP deflator index, quarterly & 1970Q1-2021Q1 & 96 & \multirow{2}{*}{$\begin{array}{l}\text { Federal Reserve Economic data; } \\
\text { IMF (IFS database; WEO database); } \\
\text { country-specific sources }\end{array}$} \\
\hline $\mathrm{DEF}_{-} \mathrm{A}$ & GDP deflator growth rate, annual & $1970-2020$ & 196 & \\
\hline CCPI_M_E & Estimated core consumer price inflation, monthly & $1970 \mathrm{~m} 1-2021 \mathrm{~m} 5$ & 156 & \multirow{3}{*}{$\begin{array}{l}\text { Authors' calculations based on } \\
\text { IMF (Consumer Price Index); } \\
\text { OECD.Stat; ILOSTAT }\end{array}$} \\
\hline $\mathrm{CCPI}_{-}^{-} \mathrm{Q}{ }_{-}^{-} \mathrm{E}$ & Estimated core consumer price inflation, quarterly & 1970Q1-2021Q1 & 157 & \\
\hline $\mathrm{CCPI}_{-} \mathrm{A}_{-} \mathrm{E}$ & Estimated core consumer price inflation, annual & $1970-2020$ & 157 & \\
\hline HCPI_Q_T & Trend component of HCPI inflation, quarterly & 1971Q1-2020Q4 & 82 & Authors' estimation based on \\
\hline $\mathrm{HCPI}_{-}^{-} \mathrm{Q} \_\mathrm{C}$ & Cyclical component of HCPI inflation, quarterly & 1971Q1-2020Q4 & 82 & Stock and Watson (2016) \\
\hline
\end{tabular}




\section{B. Group-specific aggregate inflation: Headline CPI inflation}

\begin{tabular}{|c|c|c|c|}
\hline $\begin{array}{l}\text { Variable } \\
\text { Name }\end{array}$ & Description & $\begin{array}{l}\text { Aggregation } \\
\text { Method }\end{array}$ & Sample countries \\
\hline HCPI_GLOBAL_MED & \multirow{4}{*}{$\begin{array}{l}\text { Global headline consumer price index (HCPI) } \\
\text { inflation }\end{array}$} & Unweighted median & 193 \\
\hline HCPI_GLOBAL_AVE & & Unweighted average & 193 \\
\hline HCPI_GLOBAL_AVE_GDP & & GDP-weighted average & 193 \\
\hline HCPI_GLOBAL_MED_BAL & & Unweighted median & 155 \\
\hline HCPI_AE_MED & \multirow{4}{*}{ Advanced-economy HCPI inflation } & Unweighted median & 36 \\
\hline HCPI_AE_AVE & & Unweighted average & 36 \\
\hline HCPI_AE_AVE_GDP & & GDP-weighted average & 36 \\
\hline HCPI_AE_MED_BAL & & Unweighted median & 29 \\
\hline HCPI_EMDE_MED & \multirow{4}{*}{ EMDE HCPI inflation } & Unweighted median & 157 \\
\hline HCPI_EMDE_AVE & & Unweighted average & 157 \\
\hline HCPI_EMDE_AVE_GDP & & GDP-weighted average & 157 \\
\hline HCPI_EMDE_MED_BAL & & Unweighted median & 125 \\
\hline HCPI_EAP_MED & EMDE HCPI inflation: East Asia and Pacific & Unweighted median & 24 \\
\hline HCPI_ECA_MED & EMDE HCPI inflation: Europe and Central Asia & Unweighted median & 23 \\
\hline HCPI_LAC_MED & $\begin{array}{l}\text { EMDE HCPI inflation: Latin America and the } \\
\text { Caribbean }\end{array}$ & Unweighted median & 36 \\
\hline HCPI_MNA_MED & $\begin{array}{l}\text { EMDE HCPI inflation: Middle East and North } \\
\text { Africa }\end{array}$ & Unweighted median & 19 \\
\hline HCPI_SAR_MED & EMDE HCPI inflation: South Asia & Unweighted median & 8 \\
\hline HCPI_SSA_MED & EMDE HCPI inflation: Sub-Saharan Africa & Unweighted median & 47 \\
\hline
\end{tabular}

Source: Stock and Watson (2016); Federal Reserve Economic data, Eurostat; International Monetary Fund (Consumer Price Index database, IFS database, WEO database); ILOSTAT; OECD.Stat; UNdata; central bank websites.

Note: Inflation rates are based on annual average inflation unless specified otherwise. Group-specific aggregates for other inflation measures than headline CPI inflation are defined similarly. Regional inflation is available for based on other aggregation methods (unweighted average and GDP-weighted average). 
Table 4. Number of countries with available inflation data

\begin{tabular}{|c|c|c|c|c|c|}
\hline & \multicolumn{5}{|c|}{ Number of countries with data available } \\
\hline & \multirow{2}{*}{$\begin{array}{l}\text { any year during } \\
1970-2021\end{array}$} & \multicolumn{4}{|c|}{ every year since } \\
\hline & & 1970 & 1980 & 1990 & 2000 \\
\hline \multicolumn{6}{|l|}{$\begin{array}{l}\text { Headline } \\
\text { inflation }\end{array}$} \\
\hline Annual & 193 & 155 & 158 & 166 & 187 \\
\hline Quarterly & 187 & 92 & 106 & 122 & 163 \\
\hline Monthly & 183 & 83 & 100 & 115 & 157 \\
\hline \multicolumn{6}{|c|}{ Food inflation } \\
\hline Annual & 179 & 130 & 124 & 143 & 156 \\
\hline Quarterly & 162 & 24 & 30 & 36 & 69 \\
\hline Monthly & 148 & 4 & 12 & 18 & 59 \\
\hline \multicolumn{6}{|c|}{ Energy inflation } \\
\hline Annual & 170 & 83 & 87 & 106 & 126 \\
\hline Quarterly & 148 & 19 & 25 & 30 & 60 \\
\hline Monthly & 85 & 19 & 21 & 24 & 53 \\
\hline \multicolumn{6}{|c|}{ PPI inflation } \\
\hline Annual & 113 & 30 & 33 & 39 & 67 \\
\hline Quarterly & 102 & 25 & 32 & 36 & 65 \\
\hline Monthly & 97 & 24 & 28 & 30 & 61 \\
\hline \multicolumn{6}{|c|}{ Core inflation } \\
\hline Annual & 101 & 25 & 31 & 35 & 50 \\
\hline Quarterly & 85 & 18 & 25 & 29 & 49 \\
\hline Monthly & 82 & 17 & 23 & 27 & 47 \\
\hline \multicolumn{6}{|c|}{ GDP deflator } \\
\hline Annual & 196 & 130 & 146 & 157 & 183 \\
\hline Quarterly & 96 & 13 & 15 & 24 & 66 \\
\hline Monthly & fi & fi & fi & $\ldots$ & fi \\
\hline
\end{tabular}

Note: “..." indicates that data are not available for the full sample period. Annual data stands for percent changes in yearly averages. 
Table 5. Inflation developments during the 2009 and 2020 global recessions

\section{A. 2020 global recession \\ (Percent)}

\begin{tabular}{|c|c|c|c|c|c|c|c|c|c|}
\hline & & $\mathrm{T}-4$ & $\mathrm{~T}-3$ & $\mathrm{~T}-2$ & $\mathrm{~T}-1$ & $\mathrm{~T}$ & $\mathrm{~T}+1$ & $\mathrm{~T}+2$ & $\mathrm{~T}+3$ \\
\hline \multirow{3}{*}{ PPI } & Global & 1.7 & 0.9 & 0.4 & 0.4 & -1.9 & -1.2 & -0.5 & \\
\hline & AEs & 1.1 & -0.8 & -0.8 & -1.2 & -3.5 & -2.3 & -1.7 & \\
\hline & EMDEs & 2.0 & 1.3 & 1.0 & 1.4 & -0.6 & 0.0 & 1.6 & \\
\hline \multirow[t]{3}{*}{ CPI } & Global & 2.0 & 1.5 & 1.5 & 1.5 & 1.3 & 1.8 & 1.8 & \\
\hline & AEs & 1.2 & 0.8 & 0.6 & 0.6 & 0.0 & 0.1 & 0.1 & $\# \mathrm{~N} / \mathrm{A}$ \\
\hline & EMDEs & 2.9 & 2.8 & 2.8 & 3.4 & 2.6 & 3.2 & 3.2 & \\
\hline \multirow[t]{3}{*}{ CORE } & Global & 1.9 & 2.1 & 1.9 & 1.9 & 1.4 & 1.4 & 1.5 & \\
\hline & AEs & 1.4 & 1.6 & 1.6 & 1.4 & 0.8 & 0.8 & 0.7 & \\
\hline & EMDEs & 3.0 & 2.9 & 2.7 & 2.7 & 2.6 & 2.6 & 3.3 & \\
\hline \multirow[t]{3}{*}{ Deflator } & Global & 2.3 & 2.2 & 2.1 & 2.0 & 1.6 & 1.2 & 1.5 & \\
\hline & AEs & 1.8 & 1.9 & 1.7 & 1.7 & 1.6 & 1.0 & 0.9 & \\
\hline & EMDEs & 3.3 & 2.5 & 2.8 & 3.3 & 1.6 & 3.0 & 2.3 & \\
\hline
\end{tabular}

\section{B. 2009 global recession}

(Percent)

\begin{tabular}{llccccccccc}
\hline \hline & & T-4 & T-3 & T-2 & T-1 & T & T+1 & T+2 & T+3 & T+4 \\
\hline \hline PPI & Global & 8.7 & 11.3 & 12.0 & 6.1 & 1.1 & -2.9 & -4.3 & -1.3 & 3.5 \\
& AEs & 5.7 & 7.1 & 8.7 & 3.2 & -0.1 & -4.2 & -6.8 & -2.1 & 1.1 \\
& EMDEs & 10.4 & 14.4 & 14.5 & 8.2 & 4.4 & -0.2 & -3.1 & 1.1 & 4.5 \\
& Global & 4.0 & 5.0 & 6.7 & 7.1 & 7.1 & 6.2 & 4.1 & 2.2 & 2.0 \\
& AEs & 2.8 & 3.0 & 3.2 & 2.6 & 1.9 & 1.4 & 0.2 & 0.4 & 0.9 \\
& EMDEs & 6.2 & 7.2 & 8.9 & 10.2 & 9.6 & 8.3 & 6.1 & 4.0 & 3.4 \\
\multirow{5}{*}{ Deflator } & Global & 2.9 & 3.5 & 3.9 & 3.5 & 2.7 & 2.4 & 2.1 & 1.7 & 1.8 \\
& AEs & 2.4 & 2.4 & 2.5 & 2.4 & 2.2 & 1.8 & 1.5 & 1.6 & 1.2 \\
& EMDEs & 5.6 & 6.1 & 6.9 & 7.1 & 5.5 & 4.9 & 3.9 & 3.4 & 4.0 \\
& Global & 5.0 & 6.5 & 6.1 & 5.1 & 2.5 & 1.6 & 1.1 & 1.6 & 3.0 \\
& AEs & 2.6 & 3.0 & 2.7 & 2.0 & 1.6 & 0.7 & 0.5 & 0.5 & 0.7 \\
& EMDEs & 7.5 & 9.3 & 9.8 & 8.7 & 4.7 & 3.7 & 3.0 & 3.7 & 5.1 \\
\hline \hline
\end{tabular}

Source: Kose, Sugawara, and Terrones (2019, 2020); Haver Analytics; World Bank (2020, 2021).

Note: Trend inflation quarters before and after the troughs of global recessions (shaded, $\mathrm{T}=0$ ). Global inflation is defined as median inflation (quarter over quarter, annualized) across 104 countries. Troughs of global recessions are identified using global per capita GDP and the algorithm in Harding and Pagan (2002) and are consistent with the results in Kose and Terrones (2015). Trough of global recession in 2020 is assumed to be at the second quarter of 2020. Trough of global recession around the global financial crisis is Q1 2009. "AE" = advanced economies, "EMDEs" = emerging market and developing economies. "PPI", "CPI", "CORE", "Deflator" indicate producer price index, consumer price index, core price index, and GDP implicit deflator, respectively. 
Table 6. Variance decompositions of inflation

(percent)

\section{A. Full sample}

\begin{tabular}{cccccc}
\hline \hline Factors & Import prices & PPI & Headline CPI & GDP deflator & Core CPI \\
\hline \hline \multirow{2}{*}{ Global } & 55.3 & 47.6 & 31.1 & 16.3 & 10.3 \\
& {$[52.558 .0]$} & {$[42.951 .3]$} & {$[20.941 .3]$} & {$\left[\begin{array}{lll}11.7 & 23.1\end{array}\right]$} & {$[6.813 .7]$} \\
\multirow{2}{*}{ Group } & 5.2 & 3.1 & 6.0 & 5.1 & 4.4 \\
& {$[3.07 .5]$} & {$[1.36 .0]$} & {$[1.016 .2]$} & {$[1.48 .0]$} & {$[1.68 .6]$} \\
\hline
\end{tabular}

B. Sub samples

\begin{tabular}{|c|c|c|c|c|c|c|}
\hline Periods & Factors & Import prices & PPI & Headline CPI & GDP deflator & Core CPI \\
\hline \multirow{4}{*}{$1970-86$} & \multirow{2}{*}{ Global } & 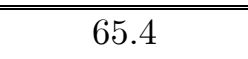 & 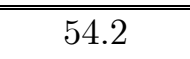 & 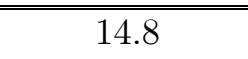 & 14.5 & 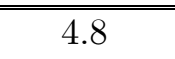 \\
\hline & & {$\left[\begin{array}{lll}54.7 & 73.1\end{array}\right]$} & {$\left[\begin{array}{ll}49.1 & 59.5\end{array}\right]$} & {$\left[\begin{array}{ll}9.6 & 19.6\end{array}\right]$} & {$\left[\begin{array}{ll}8.4 & 22.5\end{array}\right]$} & {$\left[\begin{array}{ll}3.4 & 6.8\end{array}\right]$} \\
\hline & \multirow[b]{2}{*}{ Group } & 9.0 & 6.6 & 15.2 & 17.4 & 23.8 \\
\hline & & {$\left[\begin{array}{ll}2.9 & 22.8\end{array}\right]$} & {$\left[\begin{array}{ll}1.4 & 17.4\end{array}\right]$} & {$\left[\begin{array}{ll}9.7 & 22.2\end{array}\right]$} & {$\left[\begin{array}{lll}6.4 & 36.0\end{array}\right]$} & {$\left[\begin{array}{ll}18.6 & 29.6\end{array}\right]$} \\
\hline \multirow{4}{*}{$1987-2002$} & \multirow{2}{*}{ Global } & 11.0 & 10.4 & 3.1 & 7.8 & 2.0 \\
\hline & & {$\left[\begin{array}{ll}2.7 & 29.0\end{array}\right]$} & {$\left[\begin{array}{ll}3.4 & 18.1\end{array}\right]$} & {$\left[\begin{array}{ll}0.9 & 8.2\end{array}\right]$} & {$\left[\begin{array}{ll}3.9 & 13.8\end{array}\right]$} & {$\left[\begin{array}{ll}0.3 & 5.0\end{array}\right]$} \\
\hline & \multirow{2}{*}{ Group } & 21.5 & 21.3 & 4.6 & 7.9 & 7.1 \\
\hline & & {$\left[\begin{array}{ll}3.6 & 41.2\end{array}\right]$} & {$\left[\begin{array}{ll}12.3 & 32.0\end{array}\right]$} & {$\left[\begin{array}{ll}0.7 & 11.2\end{array}\right]$} & {$\left[\begin{array}{ll}3.2 & 14.0\end{array}\right]$} & {$\left[\begin{array}{ll}1.9 & 16.5\end{array}\right]$} \\
\hline \multirow{4}{*}{$2003-2020$} & \multirow{2}{*}{ Global } & 56.0 & 66.5 & 23.7 & 16.4 & 16.2 \\
\hline & & {$\left[\begin{array}{ll}49.5 & 61.4\end{array}\right]$} & {$\left[\begin{array}{ll}58.7 & 69.2\end{array}\right]$} & {$\left[\begin{array}{lll}11.8 & 38.5\end{array}\right]$} & {$\left[\begin{array}{ll}12.2 & 20.9\end{array}\right]$} & {$\left[\begin{array}{ll}4.7 & 23.4\end{array}\right]$} \\
\hline & \multirow{2}{*}{ Group } & 10.6 & 5.4 & 2.4 & 4.9 & 7.6 \\
\hline & & {$\left[\begin{array}{ll}2.0 & 23.2\end{array}\right]$} & {$\left[\begin{array}{ll}2.0 & 9.9\end{array}\right]$} & {$\left[\begin{array}{ll}0.2 & 14.8\end{array}\right]$} & {$\left[\begin{array}{ll}1.0 & 12.6\end{array}\right]$} & {$\left[\begin{array}{ll}0.9 & 19.5\end{array}\right]$} \\
\hline
\end{tabular}

Notes: The contributions of global and group-specific inflation factors to inflation variance are estimated with a dynamic factor model for each of the five different inflation measures: Import prices, PPI, headline CPI, GDP deflator, and core CPI. The sample includes 38 countries $(25$ advanced economies and 13 EMDEs), except for import prices, which are only available for 21 countries (17 advanced economies and 4 EMDEs). The numbers in parentheses indicate the 16-84 percent confidence intervals. CPI: consumer price index; GDP: gross domestic product; PPI: producer price index. 
Figure 1. Inflation trends

\section{A. Global CPI inflation}

Percent

20

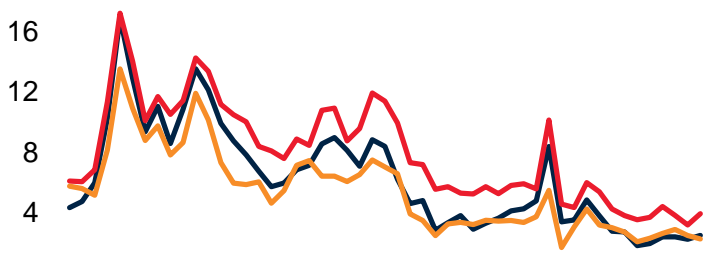

0

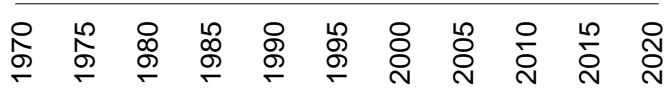

C. Inflation in LICs

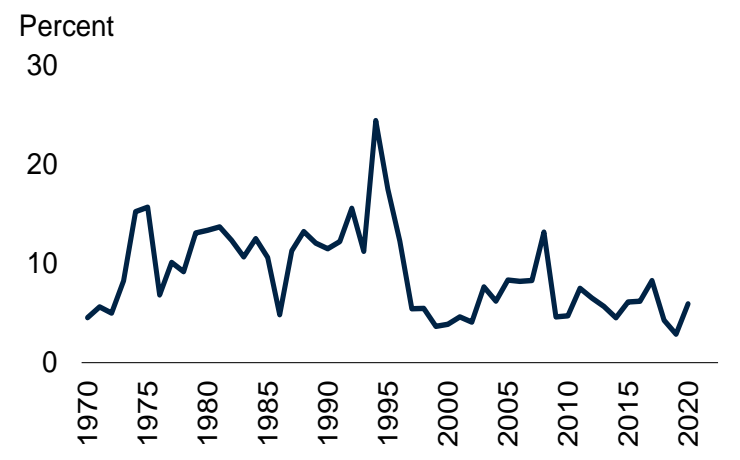

\section{B. Global CPI trend inflation}

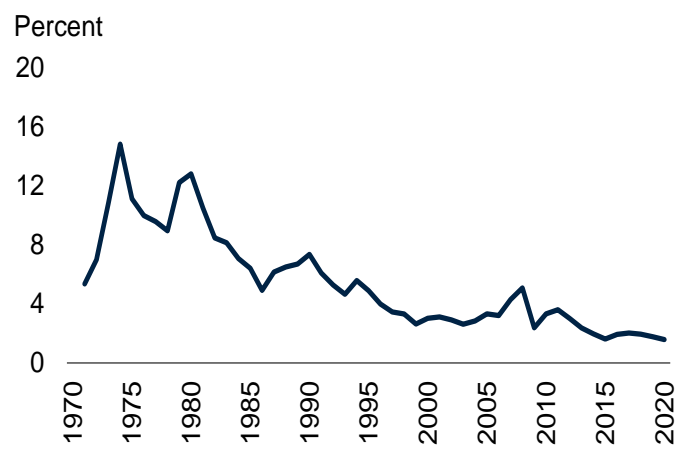

D. CPI headline inflation, by country group

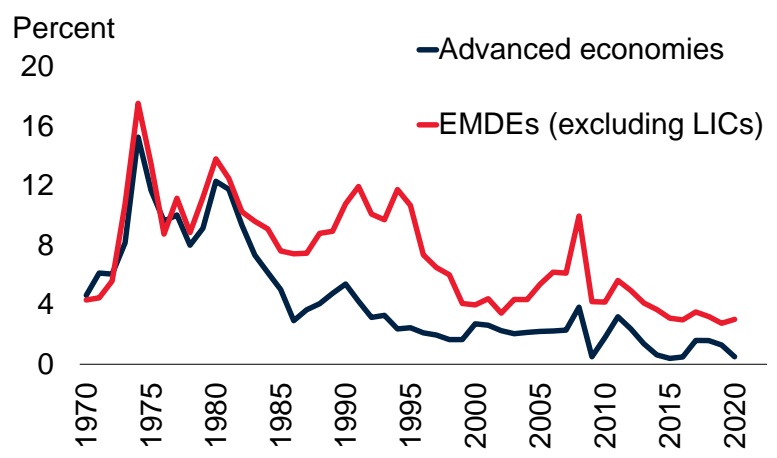

F. Global core, food, and energy inflation

E. Global CPI, PPI headline inflation, and the GDP deflator

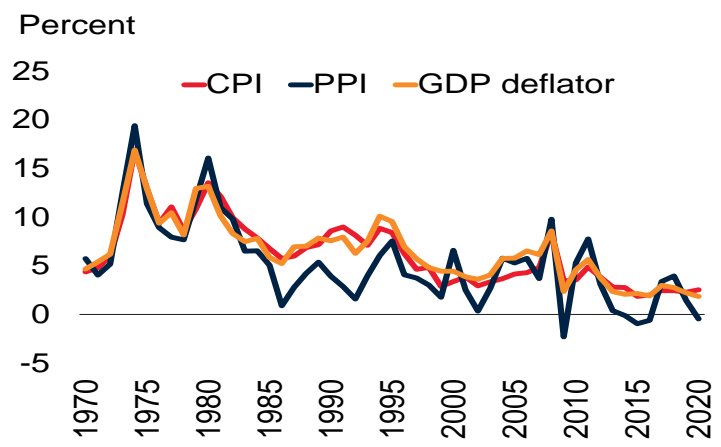

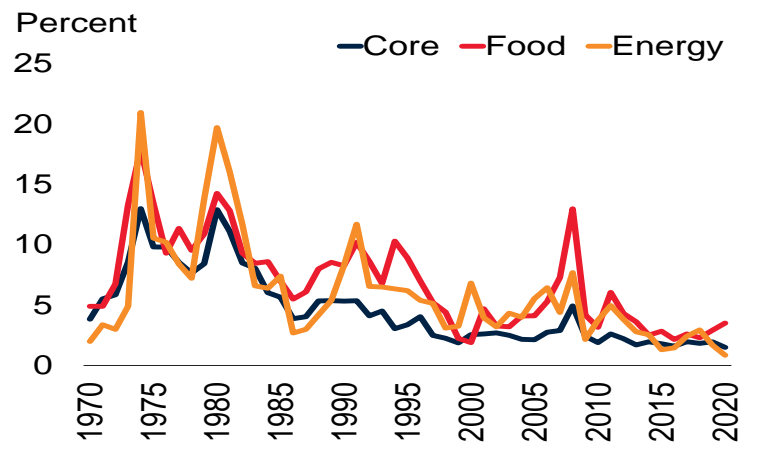

Source: World Bank.

Note: All inflation rates refer to annual average inflation. CPI = consumer price index; EMDEs = emerging market and developing economies; LICs=low income countries; PPI = producer price index.

A.C.D. Median headline CPI inflation across country groups based on a balanced set of 155 countries, including 29 advanced economies and 126 EMDEs Average and GDP-weighted average global inflation rates are based on 193 countries. Annual inflation over 50 percent are excluded from the sample; B. The values show median trend inflation of 82 countries, as defined in Stock and Watson (2016); E.F. Medians based on data for inflation in up to 196 countries. 
Figure 2. Global recessions and inflation
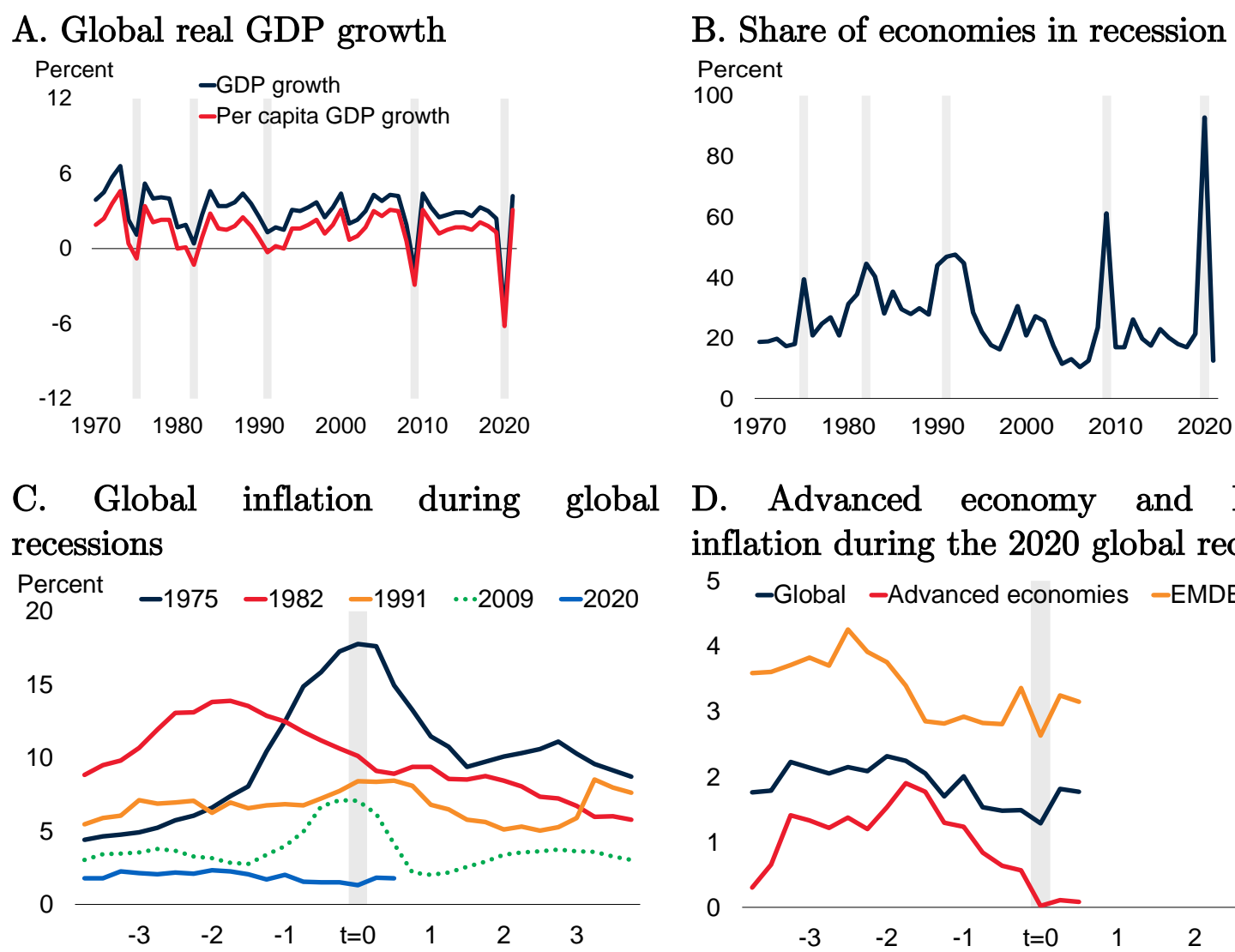

D. Advanced economy and EMDE
inflation during the 2020 global recession

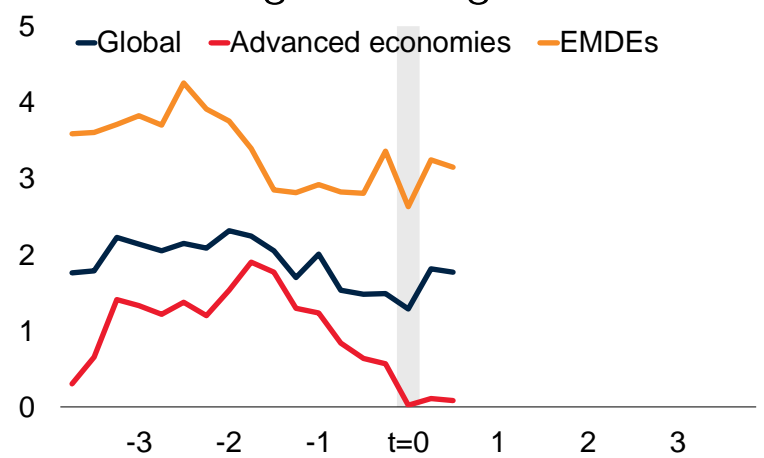

Source: Kose, Sugawara, and Terrones (2019, 2020); World Bank (2020; 2021).

Note: C.D. Horizontal axes indicate years before and after the troughs of global recessions ( $\operatorname{shaded}$ area, $\mathrm{t}=0$ ). Global inflation is defined as median inflation (4-quarter rolling average of quarterly annualized inflation ) across 76 countries, consisting of 25 advanced economies and 51 EMDEs. Troughs of global recessions are identified using global per capita GDP and the algorithm in Harding and Pagan (2002) and are consistent with the results in Kose and Terrones (2015). Trough of global recession in 2020 is assumed to be at the second quarter of 2020. "EMDEs" $=$ emerging market and developing economies. 
Figure 3. Components of inflation

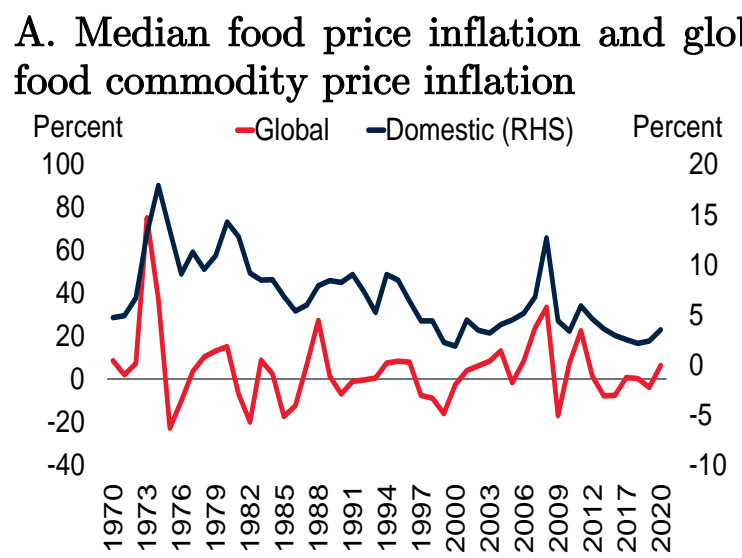

C. Correlation of national inflation cycle with global commodity price cycle

Correlation coefficient

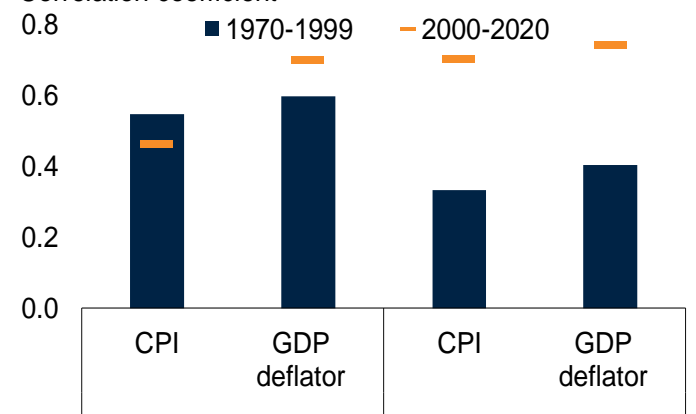

B. Median energy price inflation and global energy commodity price inflation

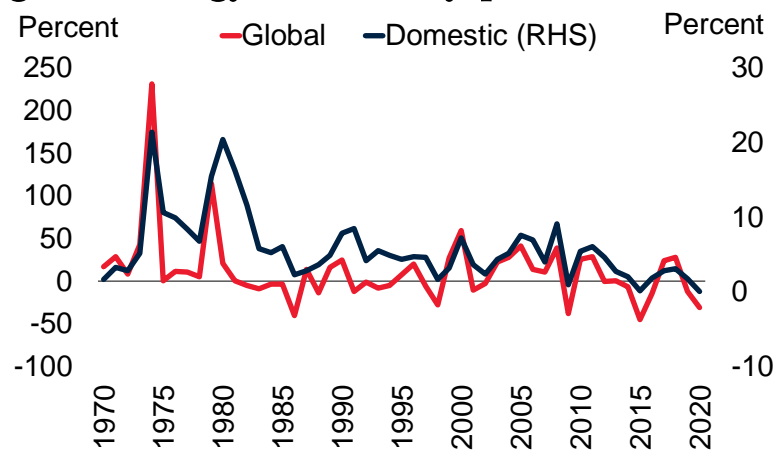

D. Correlation of national inflation cycle with global commodity price cycle

Correlation coefficient

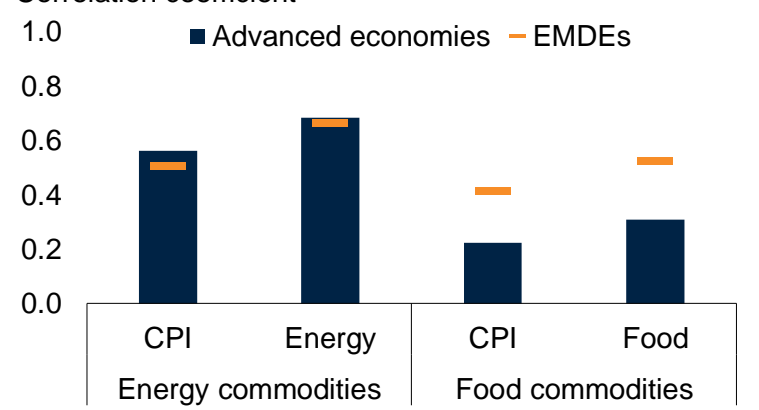

Source: Pink Sheet, World Bank.

Note: CPI = consumer price index; GDP = gross domestic product.

A.B. Inflation refers to year-on- year inflation. Global energy and food commodity price inflation from the World Bank's

Pink Sheet of commodity prices.; C. Correlation of detrended headline CPI and GDP deflator with detrended global energy and food price inflation. Detrended using the Hodrick-Prescott filter; D. Correlation between detrended domestic headline, energy, and food price inflation with detrended global energy and food price inflation. Detrended using the Hodrick-Prescott filter. 
Figure 4. Global factors for different measures of inflation
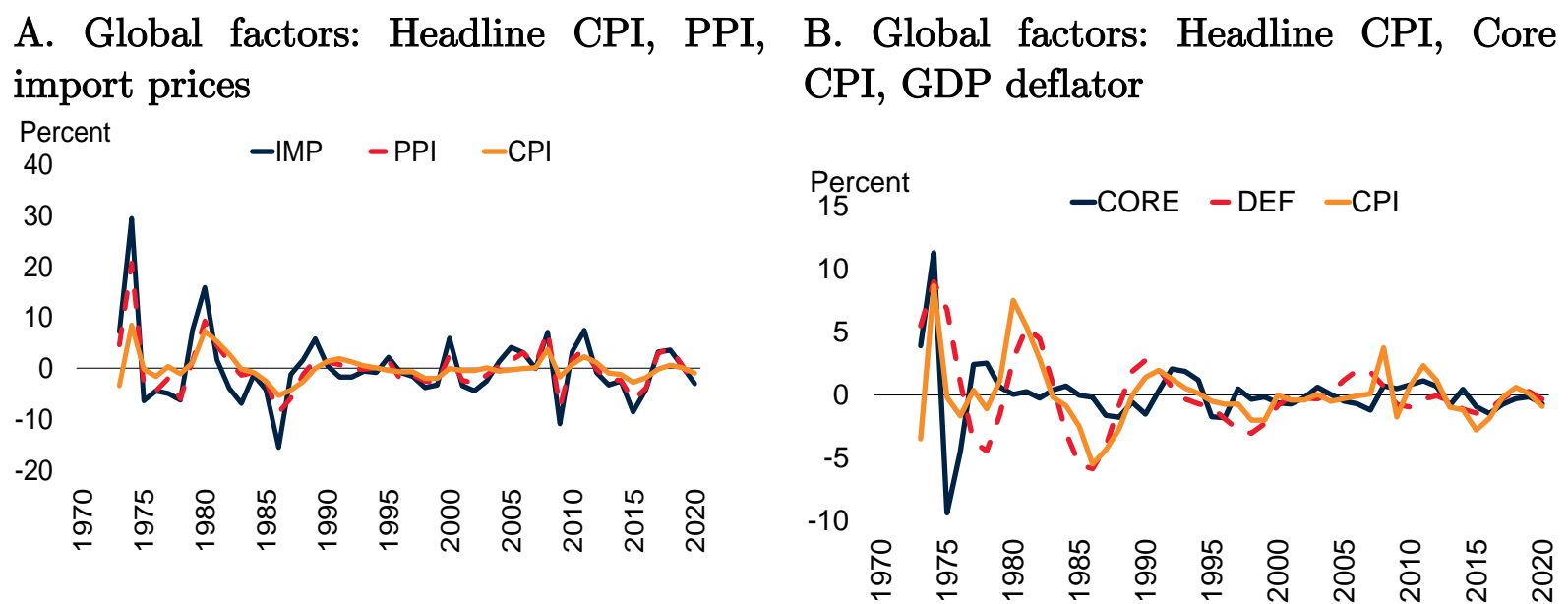

C. Advanced economies and EMDEs: Core inflation

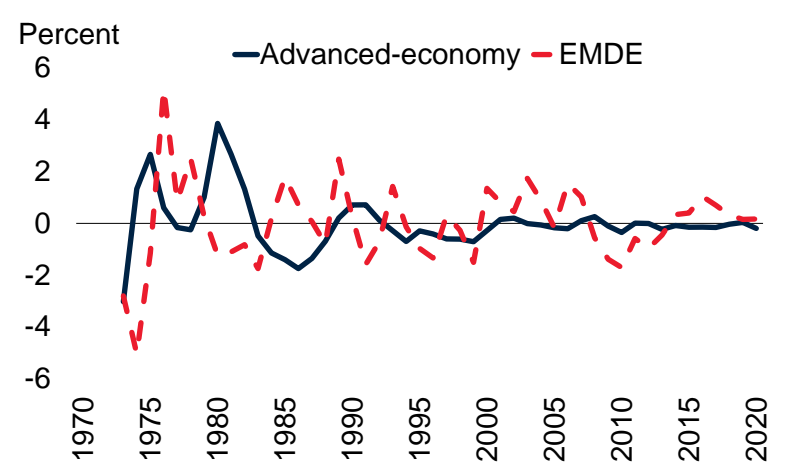

D. Advanced economies and EMDEs: Import prices

$\begin{array}{ll}\text { Percent } & \text {-Advanced-economy - EMDE }\end{array}$

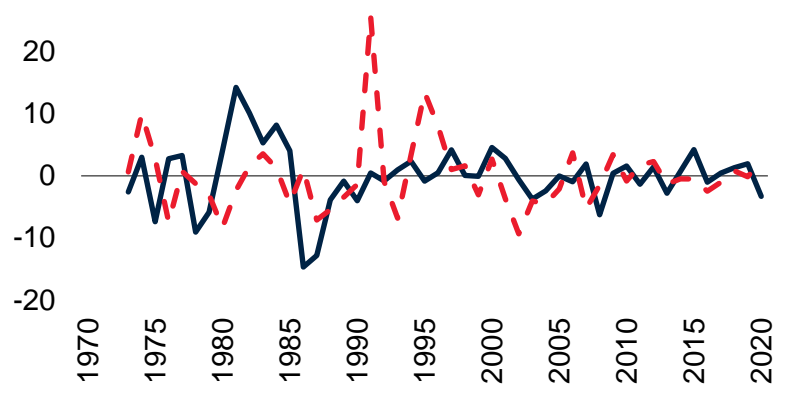

Sources: World Bank.

Note: The global inflation factors are estimated with a baseline dynamic factor model (two-factor model) for annual inflation in 38 countries (25 advanced economies and 13 EMDEs) for the period of 1971-2020. "IMP", "PPI", "CPI", "CORE", and "DEF" indicate inflation in import prices, producer prices, headline CPI, core CPI, and GDP deflator, respectively. Long-term trends are eliminated using 15-year moving average. 
Figure 5. Inflation synchronization: different measures of inflation

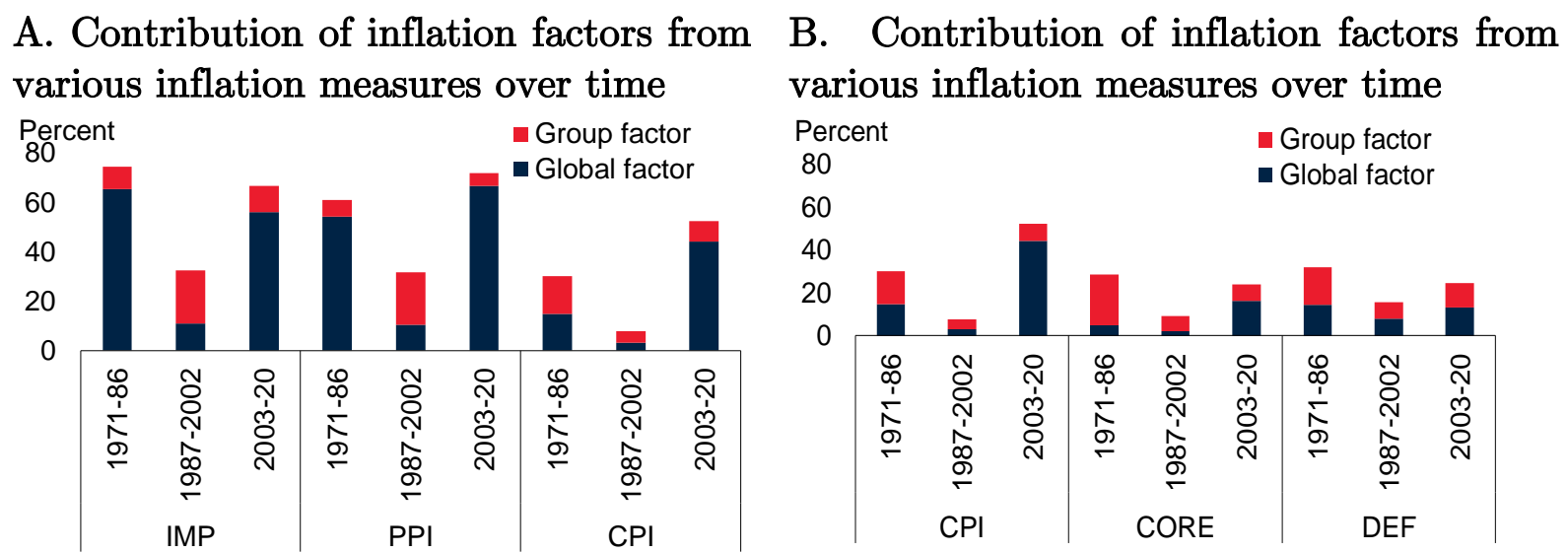

Sources: World Bank.

Notes: The global inflation factors are estimated with a baseline dynamic factor model (two-factor model) for annual inflation in 38 countries (25 advanced economies and 13 EMDEs) for the period of 1971-2020. "IMP", "PPI", "CPI", "CORE", "DEF" indicate inflation in import prices, producer price index, headline CPI, core CPI, and GDP deflator, respectively. Long-term trend is eliminated using 15year moving average. All numbers refer to sample medians. 


\title{
One-Stop Source: A Global Database of Inflation
}

\author{
July 2021

\section{Supplemental Appendix Not for Publication}

Jongrim Ha, M. Ayhan Kose, and F. Ohnsorge

\section{This appendix contains:}

Figure A1. Inflation in Latin America and Europe and Central Asia ..............................34

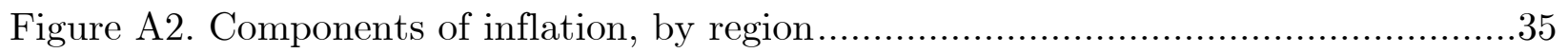

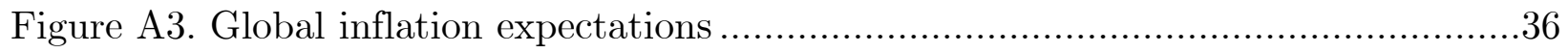

Figure A4. Deviation from inflation target ........................................................... 37

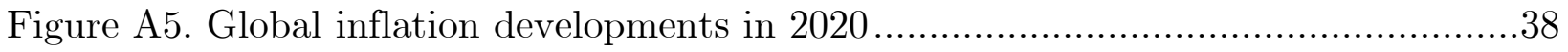

Figure A6. Inflation volatility, by region .................................................................

J. Ha: World Bank, Email: jongrimha@worldbank.org. M. A. Kose: World Bank; Brookings Institution; CEPR; CAMA; Email: akose@worldbank.org. F. Ohnsorge: World Bank; CEPR; CAMA, Email: fohnsorge@worldbank.org. We would like to thank Carlos Arteta, Matteo Ciccarelli, Alistair Dieppe, Anna Ivanova, Andreas Jobst, Atsushi Kawamoto, Gene KindbergHanlon, Christopher Towe, Filiz Unsal, and seminar participants at the World Bank and many other institutions for useful comments and suggestions during our work on this project. Hrisyana Doytchinova, Arika Kayastha, Jingran Wang, Xinyue Wang, and Heqing Zhao provided excellent research assistance. We gratefully acknowledge support from the PHRD Fund and the Knowledge for Change Program (KCP) III Fund. The findings, interpretations, and conclusions expressed in this paper are entirely those of the authors. They do not necessarily represent the views of the World Bank and its affiliated organizations. 
Figure A1. Inflation in Latin America and Europe and Central Asia

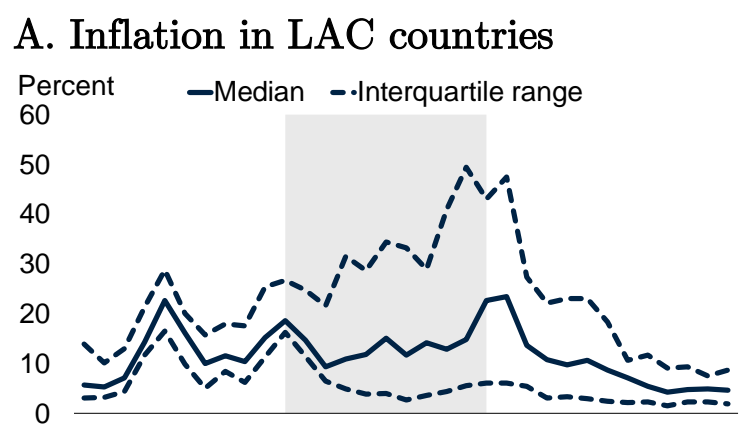

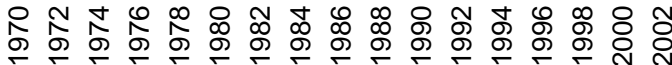

C. Share of LAC countries with inflation above 20 percent

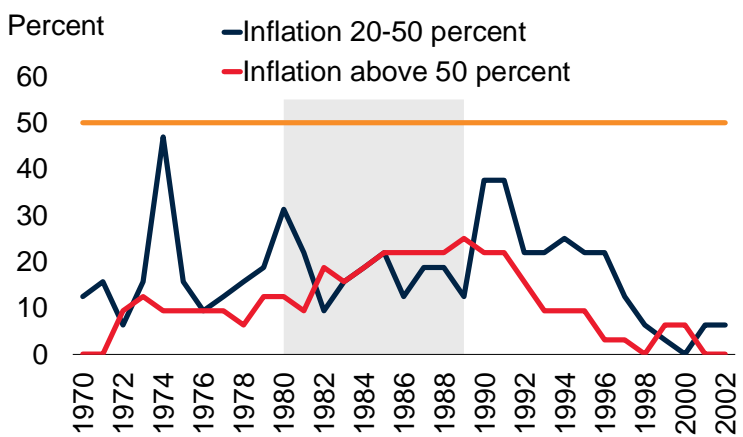

\section{B. Inflation in ECA countries}

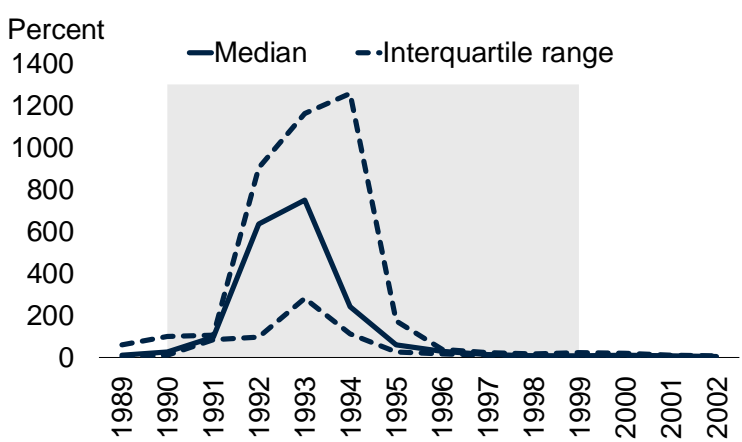

D. Share of ECA countries with inflation above 20 percent

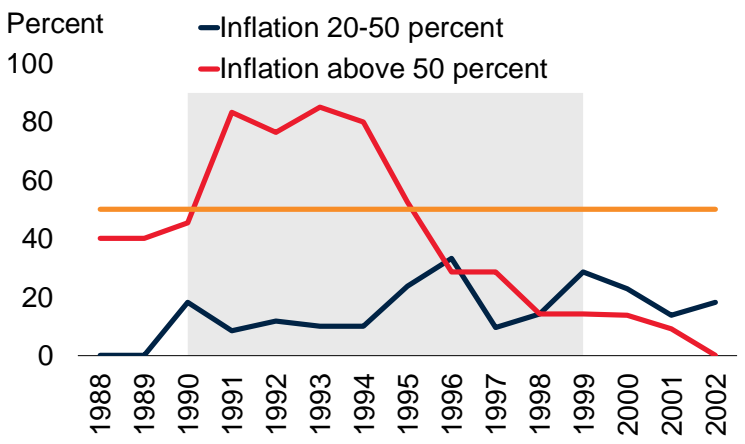

Source: World Bank.

Note: Inflation refers annual average inflation. ECA = Europe and Central Asia; LAC = Latin America and the Caribbean.

A.C. The grey area denotes the 1980s. LAC includes 32 countries in the region. The orange line in panel C indicates 50 percent of the countries. B.D. The grey area denotes the 1990s. ECA includes 22 countries in the region. The orange line indicates 50 percent of the countries. 
Figure A2. Components of inflation, by region

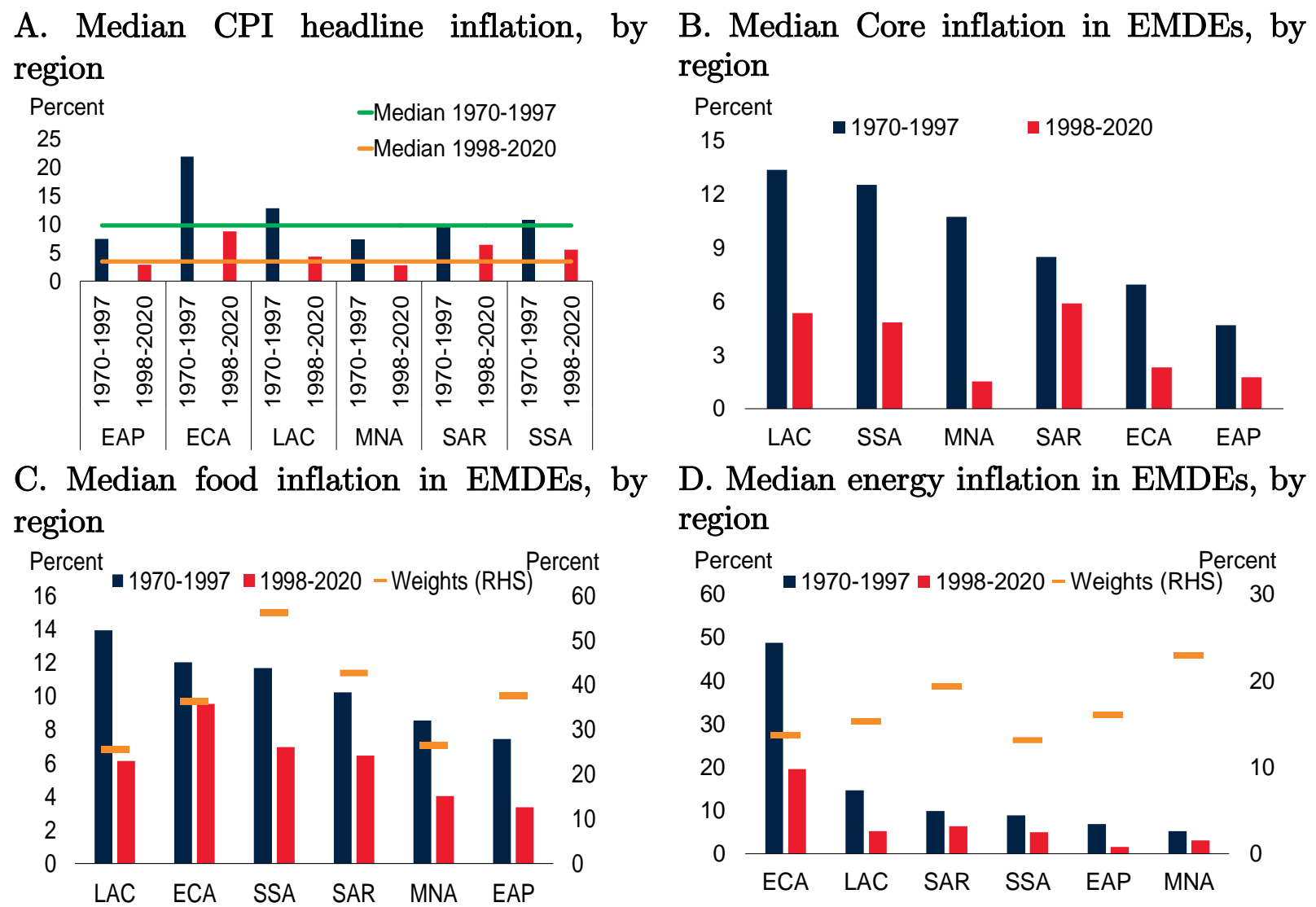

Source: Pink Sheet, World Bank.

Note: EMDEs = emerging market and developing economies; GDP = gross domestic product. All inflation rates refer to annual average inflation. $\mathrm{CPI}=$ consumer price index; EMDEs $=$ emerging market and developing economies; EAP $=$ East Asia and Pacific; ECA = Europe and Central Asia; LAC = Latin America and the Caribbean; MNA = Middle East and North Africa; SAR = South Asia; SSA = Sub-Saharan Africa.

A. Based on 155 countries.

B. Based on 87 EMDEs.

C. The horizontal lines reflect median inflation across all EMDEs over 1970-97 and 1998-2020.

C.D. Weights are food and energy weights used to calculate CPI. Weights are weights of food (C) and energy (D) in consumer price baskets. Inflation refers to year-on- year inflation. 
Figure A3. Global inflation expectations
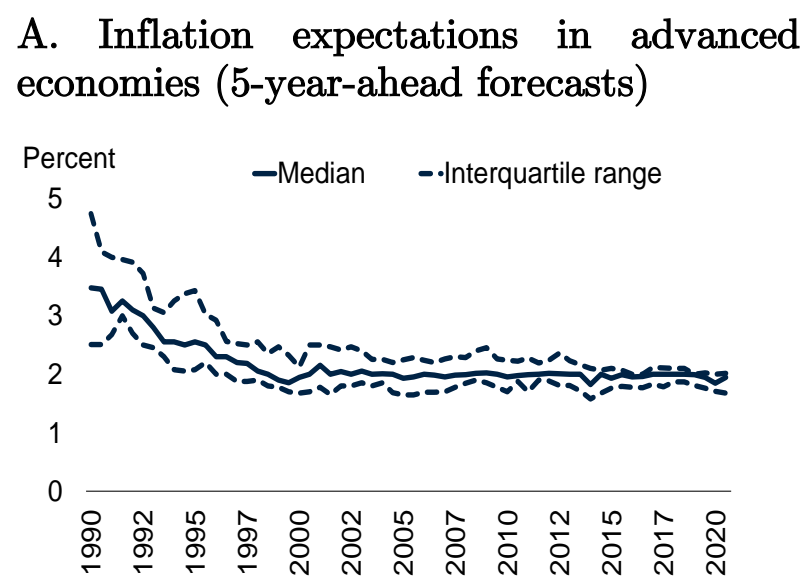

C. Share of countries with declines in 5 -year-ahead inflation expectations, 19952020

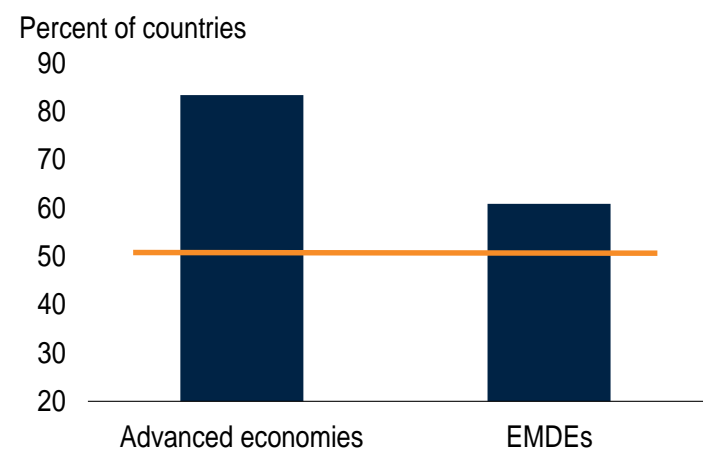

B. Inflation expectations in EMDEs (5-year-ahead forecasts)

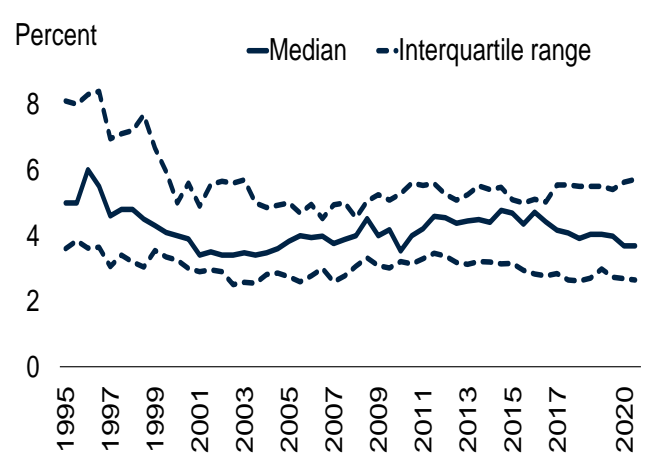

D. Five-year ahead inflation expectations in EMDEs, by central bank transparency

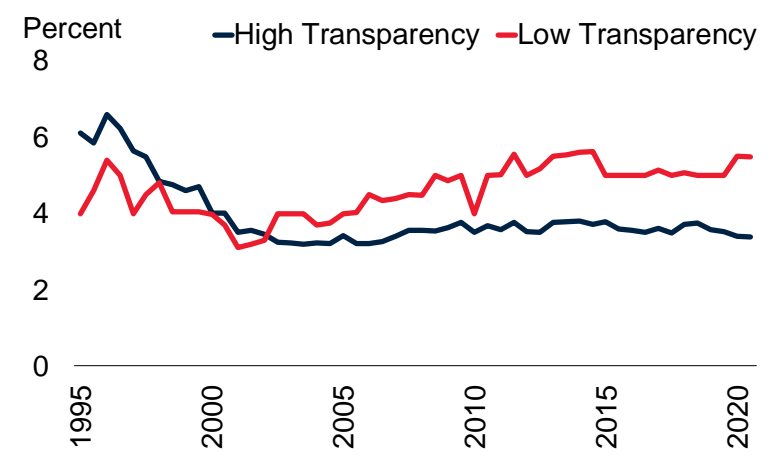

Source: Consensus Economics, International Monetary Fund, Dincer and Eichengreen 2014, World Bank. Note: EMDEs = emerging market and developing economies.

A.B. Solid lines indicate the median and dotted lines indicate the interquartile range.

C. The orange line indicates 50 percent of the countries.

D. High (low) transparency countries are defined as those with central bank transparency above the 75 th (below the 25 th)

percentile of EMDEs. The transparency data after 2016 are extended using the most recent data. 


\section{Figure A4. Deviation from inflation target}

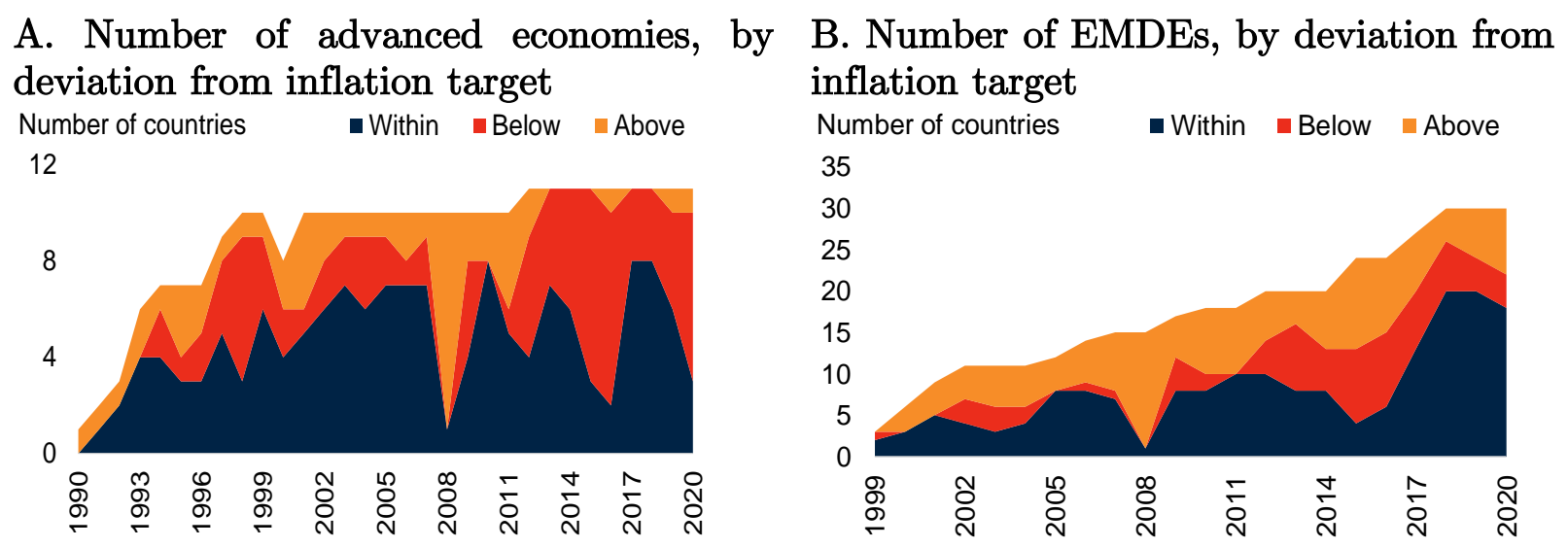

Source: Havers Analytics; World Bank.

Note: EMDEs = emerging market and developing economies. Sample includes 17 advanced economies and 27 EMDEs.

"Within" indicates the number of countries with inflation within target ranges or within j1 percentage point of the inflation target for those countries that do not announce a range

or below the inflation target for those countries that announce an inflation target ceiling. 
Figure A5. Global inflation developments in 2020

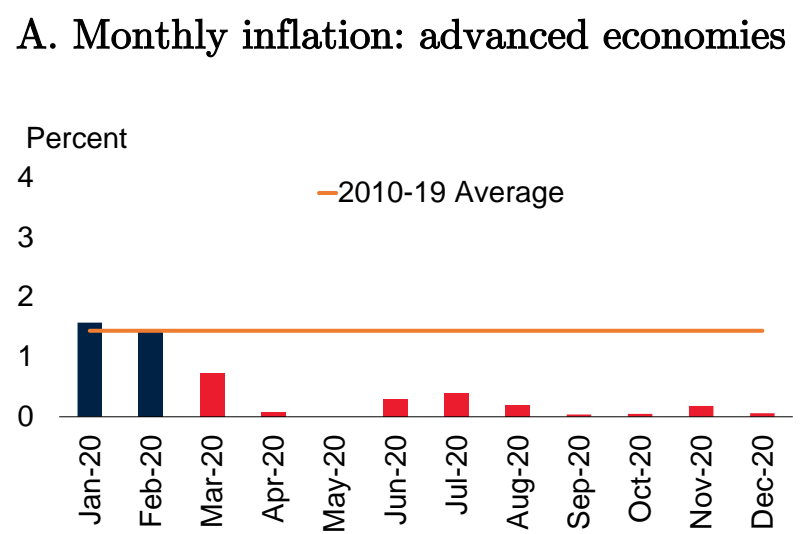

C. Quarterly EMDE inflation: by region Percent

-2010-19 average

5

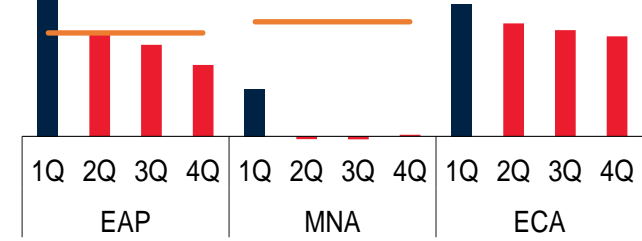

B. Monthly inflation: EMDEs

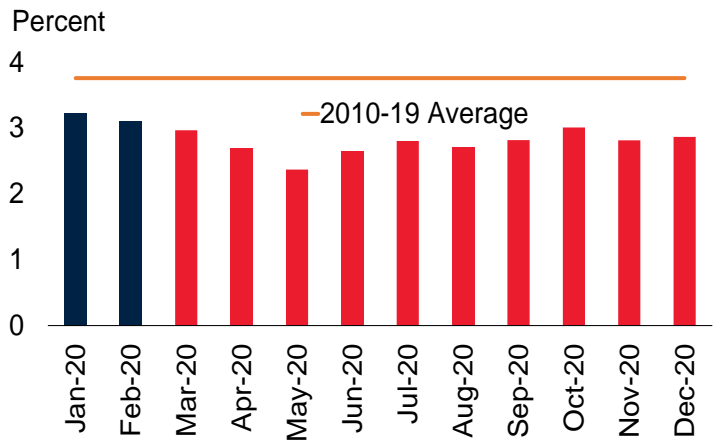

D. Quarterly EMDE inflation: by region Percent

$10 \quad-2010-19$ average

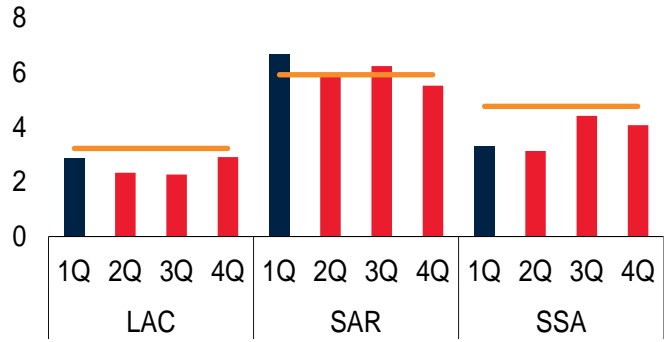

Source: Havers Analytics; World Bank

Note: Median inflation based on 140 countries (27 AEs and 113 EMDEs). The horizontal lines reflect 2010-19 average. EMDEs = emerging market and developing economies; EAP = East Asia and Pacific; ECA = Europe and Central Asia; LAC = Latin America and the Caribbean; MNA = Middle East and North Africa; SAR = South Asia; SSA = Sub-Saharan Africa. 
Figure A6. Inflation volatility, by region
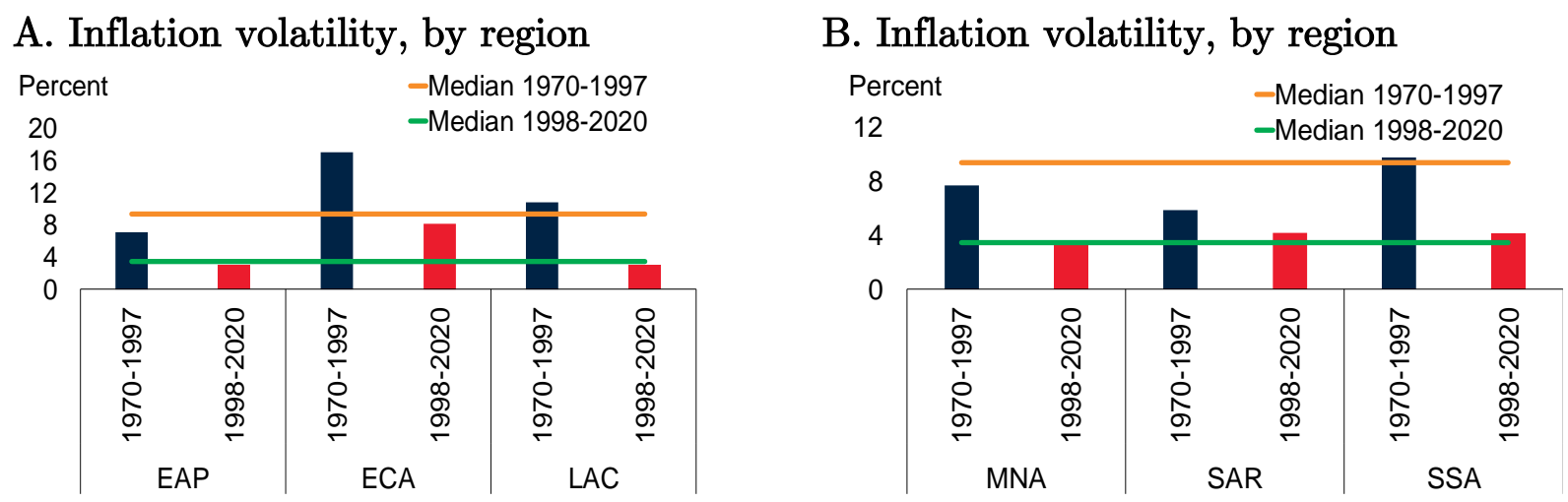

Source: Pink Sheet, World Bank.

Note: $\mathrm{EAP}=$ East Asia and Pacific; ECA = Europe and Central Asia; LAC = Latin America and the Caribbean; MNA = Middle East and North Africa; SAR = South Asia; SSA = Sub-Saharan Africa. Volatility defined as the cross-country median of the standard deviation over the corresponding periods. 